\title{
Morphologic evidence of subsurface sediment mobilization and mud volcanism in Candor and Coprates Chasmata, Valles Marineris, Mars
}

\author{
Chris H. Okubo* \\ U.S. Geological Survey, Astrogeology Science Center, 1541 E. University Boulevard, Tucson, AZ 85721, USA
}

\section{A R T I C L E I N F O}

\section{Article history:}

Received 21 October 2015

Revised 4 December 2015

Accepted 31 December 2015

Available online 15 January 2016

\section{Keywords:}

Mars, surface

Tectonics

Volcanism

Geological processes

\begin{abstract}
A B S T R A C T
Populations of distinctive knobs, rings and lobate structures are observed in the Candor and Coprates Chasmata regions of Mars. To interpret the formation mechanisms of these landforms, I investigate their morphologies, facies, superposition and crosscutting relationships using data from the High Resolution Imaging Science Experiment (HiRISE) and the High Resolution Stereo Camera (HRSC). The knobs and rings have quasi-circular to elliptical shapes in map view, with basal diameters between several hundred meters and three kilometers. The knobs rise $\sim 10$ to $350 \mathrm{~m}$ above the surrounding terrain, while the rings are $\sim 10$ to $70 \mathrm{~m}$ tall. In three dimensions the knobs have a rounded cone shape, and some knobs exhibit a summit depression, which in some examples contains a subordinate mound. The rings have rounded to sharp crests and in some instances contain subordinate rings and mounds. The lobate structures are commonly $\sim 1$ to $2 \mathrm{~km}$ wide, $\sim 3$ to $5 \mathrm{~km}$ long and rise up to $50 \mathrm{~m}$ above the surrounding terrain. The lobate structures partially or completely encircle some knobs, rings and irregularly shaped rock masses. The knobs, rings and lobate structures exhibit massive and stratified facies, with some structures exhibiting both, such as a massive central rock mass surrounded by outwardly dipping layers. I interpret these landforms as mud volcanoes, injectites and mud flows based on superposition and cross-cutting relationships as well as similarities between the morphologies and facies of these landforms with terrestrial products of mud volcanism. I infer the source of sediment for this mud volcanism to be the Hesperian eolian deposits that occur within these chasmata. Further, I suggest that groundwater upwelling during the Hesperian to possibly the Early Amazonian facilitated the mobilization of these sediments within the subsurface and thereby contributed to the ensuing mud volcanism. Based on these results, I propose that the Candor Chaos formed through subsurface sediment mobilization and mud volcanism.
\end{abstract}

Published by Elsevier Inc.

\section{Introduction}

During the Hesperian, the canyons of Valles Marineris served as sedimentary basins, accumulating stratified deposits in sequences that are several kilometers thick (Lucchitta, 1999; Okubo, 2014; Tanaka et al., 2014; Witbeck et al., 1991). These stratified sedimentary rocks provide a vital record of the transition from a wet climate, with active surface water and groundwater processes, to a more arid environment during the Late Noachian to Hesperian (Andrews-Hanna and Lewis, 2011; Andrews-Hanna et al., 2010; Bibring et al., 2006; Poulet et al., 2005). Recent large scale geologic mapping using High Resolution Imaging Science Experiment (HiRISE) (McEwen et al., 2010) data has revealed evidence of subsurface sediment mobilization in the Candor Colles region of Valles Marineris (Okubo, 2014). The purpose of this paper is to expand

\footnotetext{
* Tel.: +1 520626 0762; fax: +1 5206268998 .

E-mail address: cokubo@usgs.gov
}

upon the work of Okubo (2014) by undertaking a broader investigation of subsurface sediment mobilization and the possible discharge of these mobilized sediments onto the surface (mud volcanism) within the Candor Colles region and by documenting new evidence of these processes in the Candor Chaos region and in Coprates Chasma.

In terrestrial sedimentary basins, the mobilization of subsurface sediments is recognized as a common and significant process that acts to enhance, impede or otherwise alter local patterns of fluid migration and storage within the subsurface. These mobilized sediments often have a higher porosity and permeability than the host rock and therefore increases the volume of subsurface fluid reservoirs, improves hydraulic communication between these reservoirs, and facilitates the release of subsurface fluids into the aboveground environment (e.g., Dimitrov, 2002; Hurst and Cartwright, 2007; Huuse et al., 2010; Jonk, 2010; Kopf, 2002), including gasses of biogenic origin (Milkov, 2003). Such sediments are mobilized as slurries within the subsurface. The solid phase predominantly comprises sand, silt and clay-sized sediment, with 
lesser amounts of pebble and cobble-sized clasts. The fluid phase typically consists of water, hydrocarbons, carbon dioxide and hydrogen sulfide. A variety of processes have been identified as triggers for the mobilization of subsurface sediments including, seismicity, tectonic compression, gravity-driven compaction, hydrocarbon generation, dehydration of clay minerals, hydrothermal activity and sediment diapirism.

In the subsurface, these mobilized sediments form deposits often referred to as injectites (Chan et al., 2007; Deville et al., 2006; Huuse et al., 2010; Netoff and Shroba, 2001). The slurry can also rise to and discharge on the ground surface and sometimes recede back to depth, forming a variety of positive and negative relief landforms (Huuse et al., 2010; Kopf, 2002). Subsurface movement of injectites can be facilitated by preexisting faults, which provide pathways with lower resistance to intrusion relative to the host rock (Huuse et al., 2007; Lonergan and Cartwright, 1999).

Terms such as mud volcano, mud mound, mud ridge, mud pie, mud caldera and gryphon have been applied to the landforms produced by the discharge of mobilized subsurface sediments and fluids onto the ground surface (e.g., Fig. 1). Additionally, the term sand volcano has been used to distinguish constructs consisting of predominantly sand-sized clasts from the various landforms that comprise clay- and silt-sized particles (i.e. mud). However, this terminology is inconsistently defined and applied in the literature. Further the distinction between sand and mud volcanoes is not always meaningful, as sand and mud can be mobilized together and occur within the same landform (Frey-Martinez et al., 2007; Galli, 2000; Mazzini et al., 2007; Oppo et al., 2014; Van Rensbergen, 2005). In this paper the term mud volcano is used to refer to all edifices produced by the extrusion of mobilized subsurface sediments and fluids onto the ground surface. The term mud is strictly a textural description (cf., Folk, 1954), here encompassing sediment grain sizes of sand, clay, and silt, and is independent of mineral composition. Further, the term injectite is used to refer to the mobilized subsurface sediments that were emplaced below the contemporary ground surface. Injectite activity establishes the subsurface plumbing that feeds the development of mud volcanoes (e.g., Huuse et al., 2010; Van Rensbergen et al., 2003).

The patterns of fluid flow established by injectite and mud volcano systems can be areally extensive and persist for millions of years (Hurst and Cartwright, 2007; Milkov, 2000; Van Rensbergen et al., 2003) and therefore have a substantive impact on hydrologic, geologic and biologic processes within the surrounding environment. Due to their sustained flux of fluids, subaerial mud volcanoes on Earth are oases for bacterial and archaeal communities (Alain et al., 2006; Green-Saxena et al., 2012; Kokoschka et al., 2015; Wrede et al., 2012). Submarine mud volcanoes are sites of more complex ecosystems that include higher order organisms (Lazar et al., 2011; Olu-Le Roy et al., 2004; Pachiadaki et al., 2011; Soltwedel et al., 2005). Past biologic systems associated with mud volcanoes have been studied using fossil assemblages and other biomarkers (Campbell, 2006; Cavagna et al., 1999; Clari et al., 2009; Vanneste et al., 2012). Therefore, mud volcano systems are important sites for investigating the geologic processes that could have supported past habitable environments on Mars and for seeking evidence of past life in the form of fossils and other preserved biomarkers. Additionally, mud volcanoes provide access to otherwise inaccessible strata, in the form of the extruded muds and xenoliths therein.

\section{Geologic setting}

Valles Marineris is a $4000 \mathrm{~km}$ long network of interconnected canyons in the western equatorial region of Mars. It was discovered in images acquired by the Mariner 9 television experiment in 1972 (McCauley et al., 1972), which revealed that many of Valles
Marineris' canyons contained prominently stratified rocks, with an albedo higher than the bedrock exposed in the chasma walls but moderate overall for Mars. Subsequent map-based and thematic studies (e.g., Andrews-Hanna, 2012a, 2012b, 2012c; Fueten et al., 2014; Lucchitta, 1999; Lucchitta et al., 1992; Okubo, 2010; Peulvast and Masson, 1993; Schultz, 1998; Scott and Tanaka, 1986; Tanaka et al., 2014; Witbeck et al., 1991) have generally shown that development of Valles Marineris began during the Middle to Late Noachian with the development of rift systems in the Noachian volcanic, impact regolith and various other sedimentary sequences that make up the bulk of the Thaumasia highlands; these rocks are presently exposed along the chasma walls as variously stratified materials, but commonly buried by colluvial fans. Rifting and regional volcanism became prominent and areally extensive during the Late Noachian to Early Hesperian. Simultaneously, large floods of water were discharged from Valles Marineris, which formed the large-scale chaotic terrains and associated outflow channels located east toward Chryse Planitia. During this time, the stratified, moderate albedo rocks (described below) also began to accumulate within Valles Marineris as well as on the surrounding plains. Rift-related normal faults deformed these strata during the Hesperian. The floors of the chasmata were then covered by landslides, debris flows and other mass wasting deposits derived from not only the chasma walls but also from the stratified rocks located within the isolated and coalesced chasmata. Accumulation of the stratified rocks ceased within Valles Marineris during the Amazonian, while mass-wasting deposits continued to accumulate on the floors and lower walls of the chasmata. Eolian erosion became the dominant geologic process extending into the present day.

The origins of the stratified rocks within the various chasmata (canyons) of Valles Marineris have been extensively studied. Though various landforms and textural units have been interpreted as spring mounds (Rossi et al., 2008), salt diapirs (Baioni and Wezel, 2010; Baioni, 2013) or volcaniclastic sediments and lava flows associated with subglacial volcanoes (Chapman and Tanaka, 2002, 2001; Komatsu et al., 2004; Lucchitta et al., 1994), the majority of recent investigations suggest much of the chasma-related strata consists principally of clastic sediments. The proposed provenance of these clastic sediments encompasses assorted - often overlapping - eolian, fluvial, lacustrine and volcanic processes (e.g., Fueten et al., 2014, 2011, 2008, 2005; Hynek et al., 2003; Lucchitta, 1999; Mangold et al., 2008; Metz et al., 2009; Michalski and Niles, 2012; Murchie et al., 2009; Okubo, 2014; Quantin, 2005; Sowe et al., 2007; Stack et al., 2013; Weitz et al., 2015; Witbeck et al., 1991). The present study focuses on landforms within the stratified rocks located in the Candor Colles and Candor Chaos regions of Candor Chasma, as well as in central Coprates Chasma.

Candor Chasma is an $\sim 800 \mathrm{~km}$ long, $\sim 140 \mathrm{~km}$ wide canyon in central Valles Marineris (Fig. 2). In places, the floor of this chasma lies $9.5 \mathrm{~km}$ below the adjacent canyon rim. Stratified sedimentary rocks cover most of the floor of the chasma. These rocks form broad mensae (mesas) along the midline of the chasma, including Ceti, Candor and Baetis Mensae in west and Nia and Juventae Mensae in the east. The summits of these mensae can approach (but do not equal or exceed) the elevation of the adjacent canyon rims, and the mensae are typically separated from the adjacent canyon walls by broad topographic lows.

The Candor Colles are a population of knobs located on the lower, southeast-facing slopes of Ceti Mensa, within the topographic low that separates this mensa from the south wall of Candor Chasma (Fig. 2). Large-scale geologic mapping through the central part of the Candor Colles suggests that the local bedrock comprises eolian sand sheets and sand dunes that were deposited in a wet playa environment (Okubo, 2014), likely during the Hesperian (Tanaka et al., 2014). 


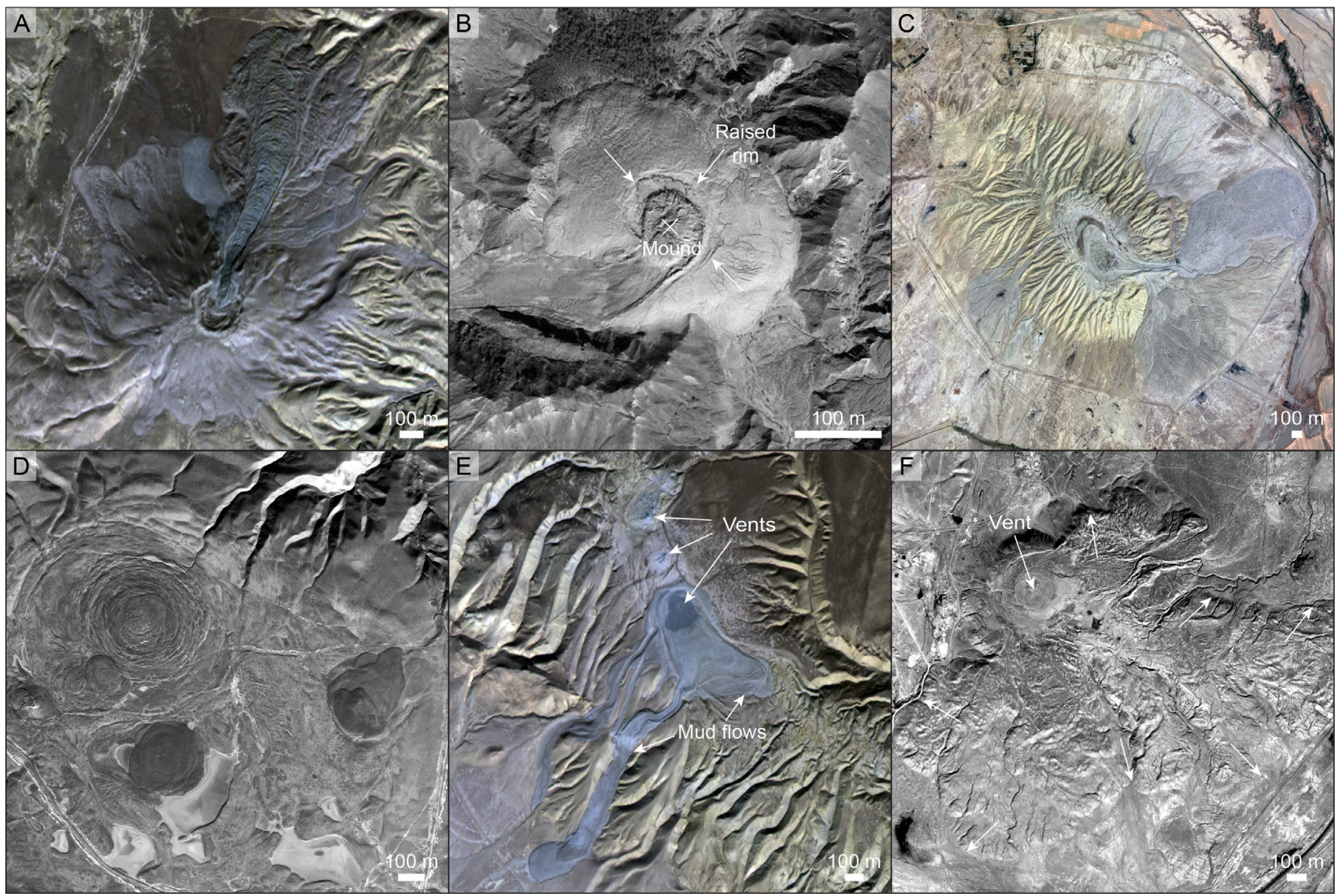

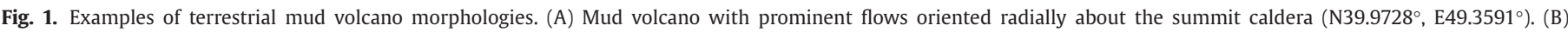

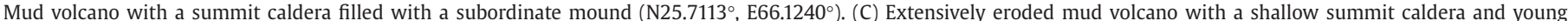

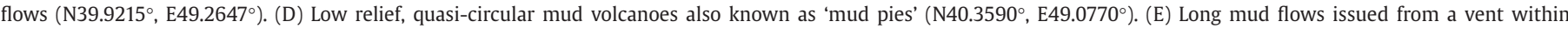

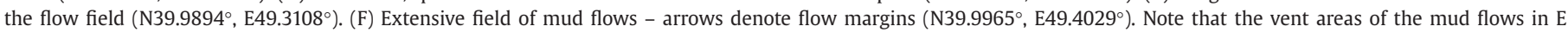

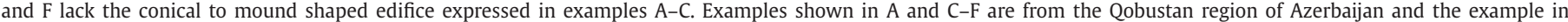
$\mathrm{B}$ is from the Makrān region of Pakistan. Data are from OrbView-3.

The Candor Chaos is a region of closely spaced mesas, knobs, hills and ridges in central Candor Chasma (Fig. 2). Candor Chaos lies within the topographic low between high standing mesas of stratified sedimentary bedrock to the west, north and east (e.g., Candor and Baetis Mensae). The southern portion of Candor Chaos abuts the south wall of Candor Chasma. The Candor Chaos developed within sediments comprising Middle Amazonian mass wasting deposits that superpose Hesperian eolian deposits (Tanaka et al., 2014).

The floor of Coprates Chasma is a broad expanse that lacks the high standing mounds of stratified sedimentary bedrock that typifies the interior of Candor Chasma (Fig. 2). Numerous landslides, impact craters and massifs are present on the otherwise flat floor. Of interest to this study are the smaller knobs, hills and ridges that are scattered along the chasma floor. These landforms developed within Late Hesperian mass wasting, fluvial and lacustrine sediments and the underlying Hesperian eolian deposits (Tanaka et al., 2014).

\section{Subsurface sediment mobilization and mud volcanism on Mars}

Evidence of subsurface sediment mobilization processes on Mars, including mud volcanism, has been previously reported. Knobs with summit depressions, rounded knobs and lobate struc- tures have been observed in the northern plains regions and interpreted as the result of mud volcanism (Farrand, 2005; Ivanov et al., 2015, 2014; Komatsu et al., 2011; McGowan, 2011; Oehler and Allen, 2012, 2010; Skinner and Tanaka, 2007; Tanaka et al., 2011, 2005; Tanaka, 2003a, 2003b). Crater counts indicate that mud volcanism in the northern plains occurred during the Hesperian to Early Amazonian (Skinner and Tanaka, 2007). Interpretations of mud volcanoes have also been reported from Argyre basin (Dohm et al., 2015) and from Arabia Terra, within the sedimentary mounds in Firsoff crater (Pondrelli et al., 2011) and Crommelin crater (Franchi et al., 2014). Other evidence of subsurface sediment mobilization may be found in the large ovoid and knobby mountains in the Scandia Tholi and elsewhere in the northern plains (Skinner and Mazzini, 2009), as well as the ubiquitous thumbprint terrain also in the northern plains (Skinner and Tanaka, 2007).

Alternative interpretations of these landforms have also been proposed. In the northern plains, knobs with summit depressions, rounded knobs and lobate structures have been interpreted as the results of igneous volcanism (Bridges et al., 2003; Frey and Jarosewich, 1982; Frey et al., 1979; Lanz et al., 2010). Another alternative interpretation of these landforms is that they are pingos (de Pablo and Komatsu, 2009). However, the morphologies of these landforms are markedly different from the flat-topped mound and fractured mound morphologies of other proposed pingos in the northern plains (Dundas et al., 2008). 


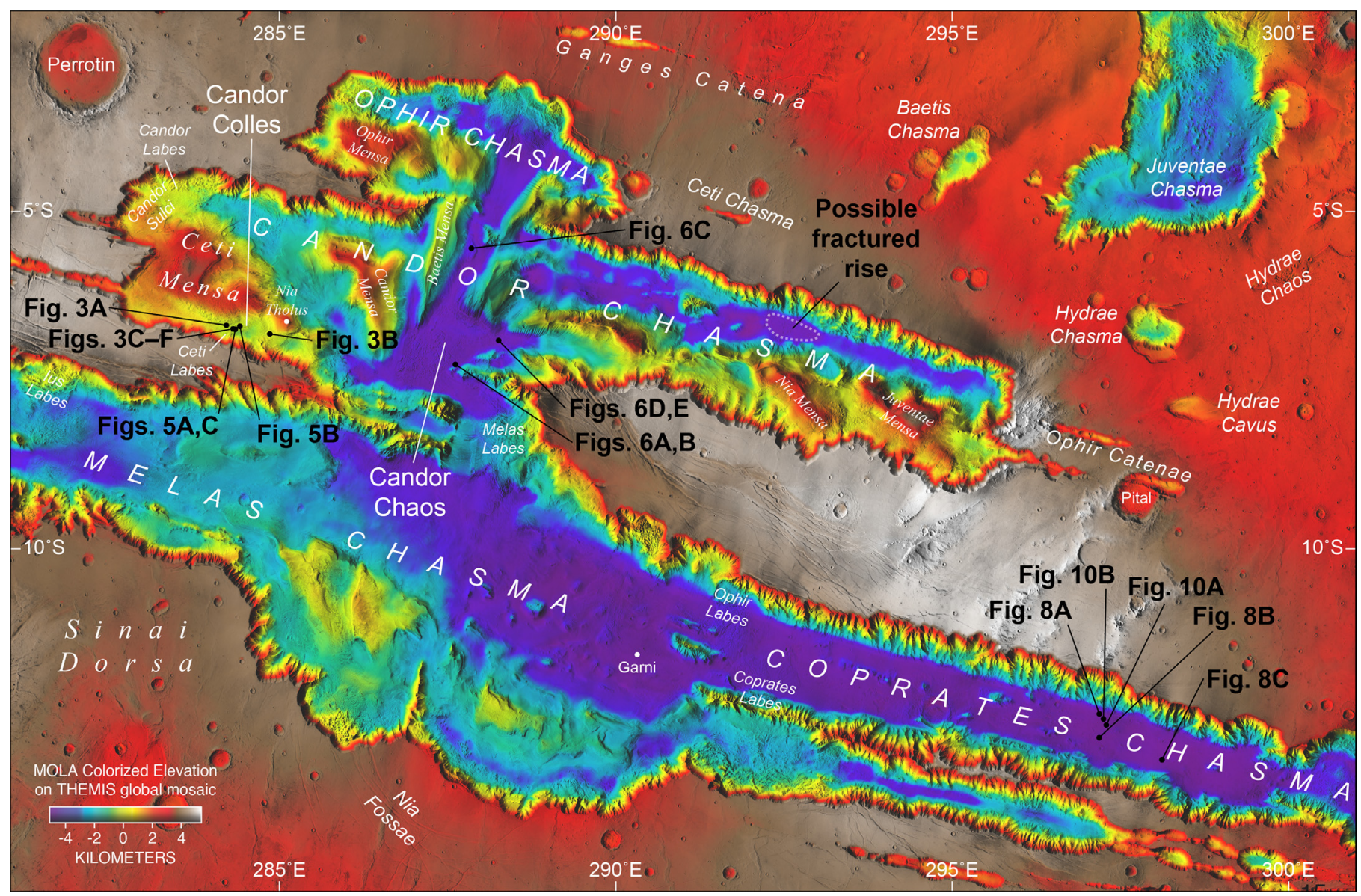

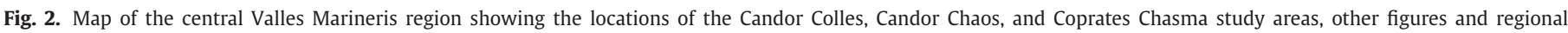
geographic features.

Knobs with summit depressions, rounded knobs and lobate structures have been previously documented in Candor Chaos (Lucchitta, 1990) and Coprates Chasma (Brož et al., 2015) regions of Valles Marineris. These previous studies proposed that the landforms are the products of igneous volcanism (Brož et al., 2015; Lucchitta, 1990).

Additional evidence of subsurface sediment mobilization on Mars, albeit at a much smaller scale has been reported from surface observations in Gale crater. At the Yellowknife Bay locality, a tabular, low-albedo seam that crosscuts mudstone and sandstone deposits was investigated by the Mars Science Laboratory rover (Grotzinger et al., 2014). This seam is $6-10 \mathrm{~cm}$ wide and $\sim 5 \mathrm{~m}$ long. Grotzinger et al. (2014) interpreted this seam as an injectite dike based on its fine-grained texture, basaltic composition, and upwarping of adjacent sedimentary layers.

Injectites at a significantly larger scale have been identified in the western part of Candor Chasma. Large scale geologic mapping suggests that the Candor Colles may be the erosional remnants of injectite pipes (Okubo, 2014), where liquefaction appears to have mobilized the clastic sediments that constitute the local bedrock. Seismicity attendant with multiple slope failures and landsliding of these sediments is the interpreted trigger for liquefaction. The architecture of the fault damage zones that define the basal detachment surfaces of these landslides provides independent evidence that these sediments were porous and poorly consolidated (and thus prone to liquefaction) at the time of slope failure (Okubo, 2014). Additionally, rounded knobs in other parts of west Candor Chasma (outside of the Candor Colles) may also be the erosional remnants of injectites (Chan et al., 2010).
Though Okubo (2014) presented compelling evidence for the presence of injectites within west Candor Chasma, only a small subset of landforms in the Candor Colles region was examined. Okubo (2014) also did not address possible surface expressions of this injectite activity, such as mud volcanoes. In the following sections, I expand upon the work of Okubo (2014) by discussing the greater diversity in landform morphology observed within the wider Candor Colles population, present new interpretations of the pre-erosional structure and morphology of the Candor Colles, and discuss the present day morphologies and origins of similar landforms in Candor Chaos and Coprates Chasma.

\section{Data and methods}

Candidate landforms were identified using map projected Context Camera (CTX; Malin et al., 2007) images displayed in the Java Mission-planning and Analysis for Remote Sensing (JMARS) software. Footprints of HiRISE and High Resolution Stereo Camera (HRSC) (Jaumann et al., 2007) images and digital elevation models (DEMs) were rendered in JMARS to identify those landforms that are covered by HiRISE and HRSC data. Due to their availability and broad areal coverage, HRSC DEMs provided the bulk of the topographic data used. Anaglyphs comprising stereo HiRISE images were used to assess the landforms' meter-scale morphologies and qualitative structure (e.g., dip directions of layers) in areas where a HiRISE DEM was not available. All HiRISE images (stereo and non-stereo) available in each study area were used to develop the observations and interpretations presented in this paper 


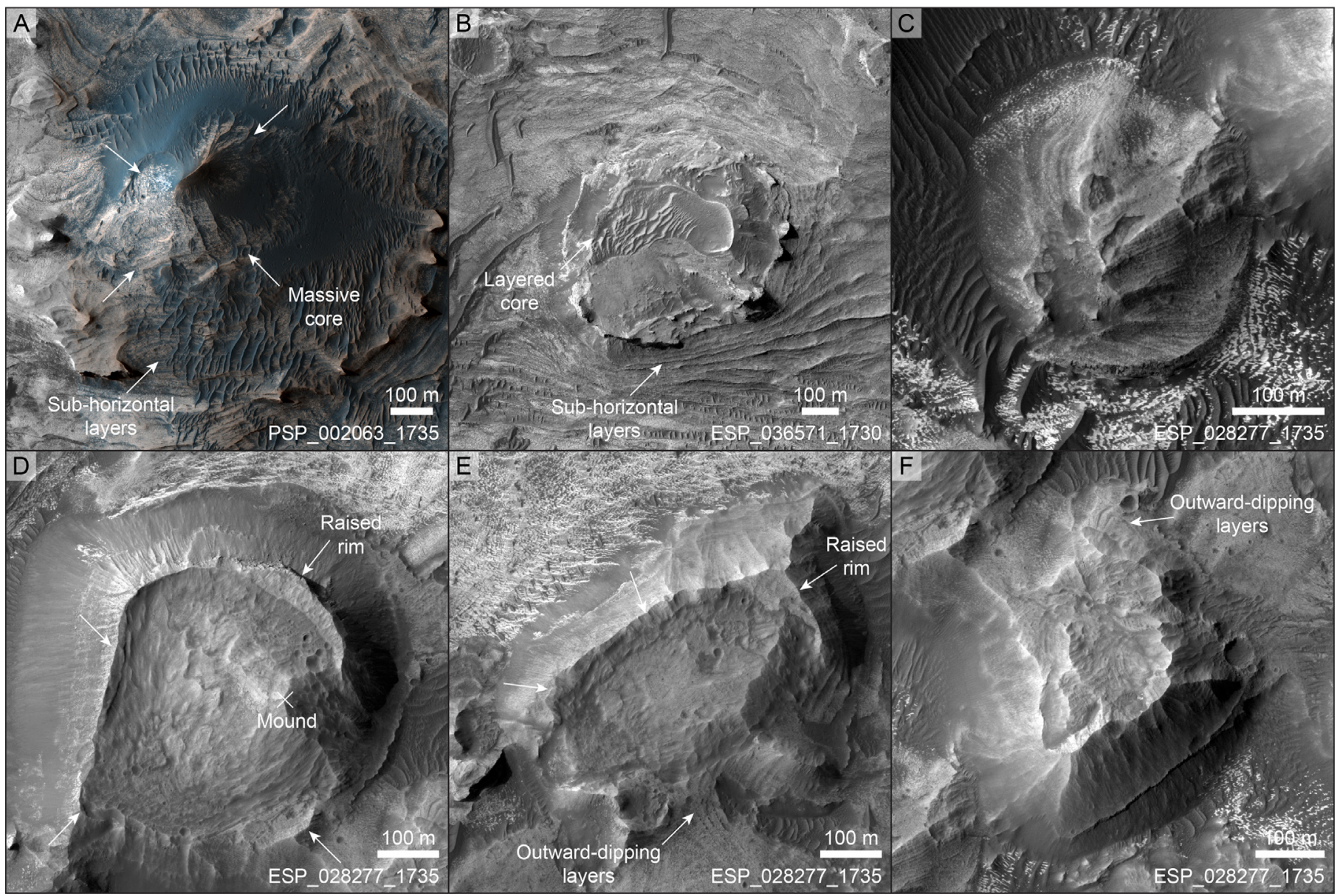

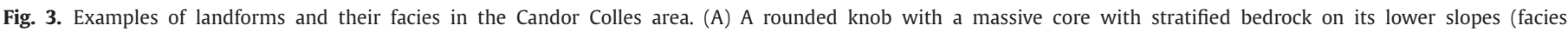

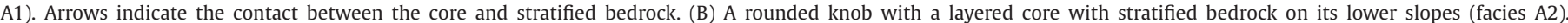

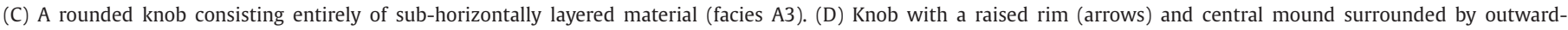

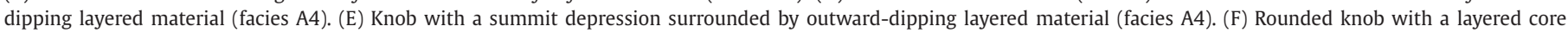

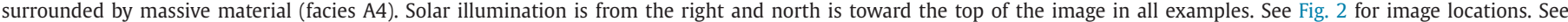
Fig. 4 for a complete synopsis of the facies observed in the Candor Colles area.

(Supplementary Table 1). All data used in this work are available through the NASA Planetary Data System (PDS).

Images and DEMs were imported into the U.S. Geological Survey's Integrated Software for Imagers and Spectrometers (ISIS) using ISIS' pds2isis program. Data visualization and extraction of topographic profiles were done using ISIS' qview program. The HiView program distributed by the HiRISE team was used to view individual images. HiRISE anaglyphs were viewed in Adobe ${ }^{\circledR}$ Photoshop $^{\circledR}$, which allows for translation of the anaglyphs' red channel to optimize parallax and ease of viewing.

\section{Candor Colles}

Knobs in the Candor Colles region display a discrete set of characteristic morphologies. In map view, the knobs are quasicircular to irregular in shape (Fig. 3). Quasi-circular knobs have basal diameters of $\sim 0.2$ to $1 \mathrm{~km}$, which is comparable in length to the long axes of the irregularly shaped knobs. In three dimensions some knobs exhibit a rounded cone or mound shape (Fig. 3A). Other knobs are topped by a raised rim that partially or completely surrounds either a central mound (Fig. 3D) or a central depression (Fig. 3E). The knobs rise up to $\sim 0.01$ to $0.1 \mathrm{~km}$ above the surrounding terrain.

Knobs that do not possess a central mound commonly exhibit distinct masses of rock within their central, upper regions - either within a central depression (Fig. 3E) or around their apex (Fig. 3A, B and F). These central masses (including the central mounds) exhibit surface textures, albedo, and stratification that are distinct from the material that constitutes the outer slopes of the knobs. The central masses commonly exhibit a fluted surface that appears smooth at HiRISE resolution - no clasts larger than $0.25 \mathrm{~m}$ in diameter are observed. The central masses typically have an albedo that is lower than the adjacent stratified sedimentary bedrock. Further, the central masses are either massive (structureless) (Fig. 3A) or exhibit sub-horizontal parallel to nonparallel stratification (Fig. 3B). The contact between the central masses and the rock forming the outer slopes of the colles typically exhibits a low albedo and a break in slope.

Just as with the central rock masses, the rock that constitutes the outer slopes of the knobs is observed to be either massive or stratified. Within the stratified subset, layering is either sub-horizontal (Fig. 3A and B) or dips outward, away from the center of knob (Fig. 3E and F). Layers that are outward dipping are also non-conformable with the subjacent sedimentary bedrock - there is a distinct unconformity between the bottom of the knob and the bedrock. These outward-dipping layers superpose the bedrock. Further, layers within the horizontally stratified outer slopes are conformable with the subjacent bedrock at some knobs (Fig. 3A), while these layers are non-conformable with the subjacent bedrock at other knobs (Fig. 3C). 

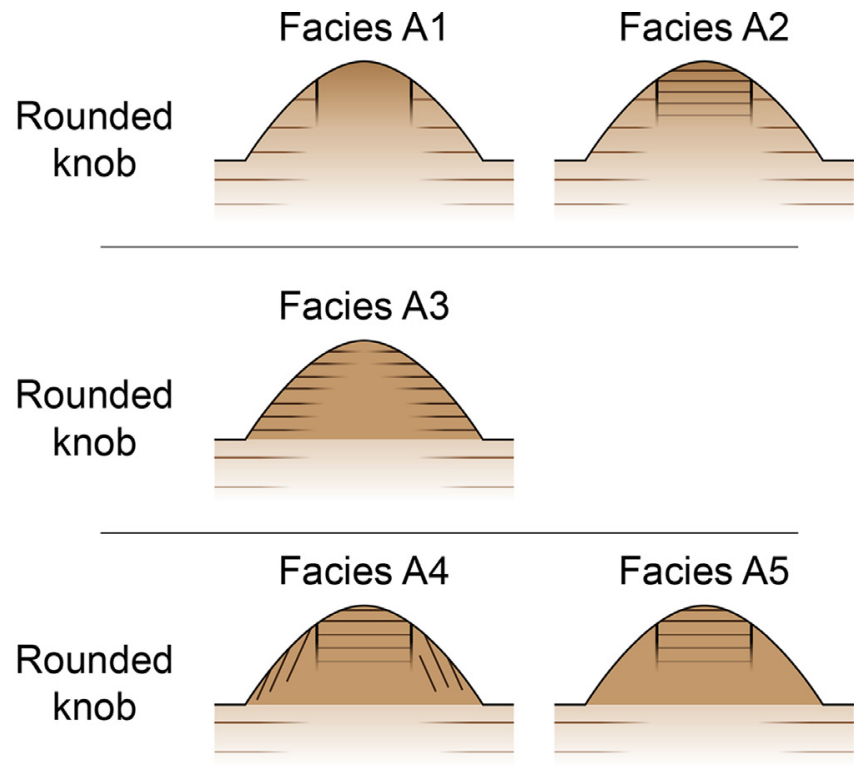

\section{Knob with summit depression}
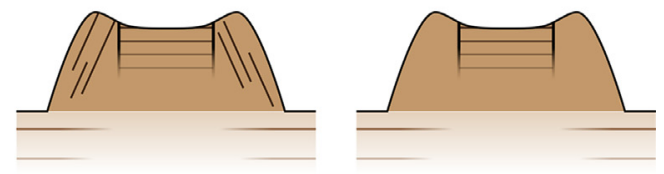

\section{Knob with raised rim and central mound}
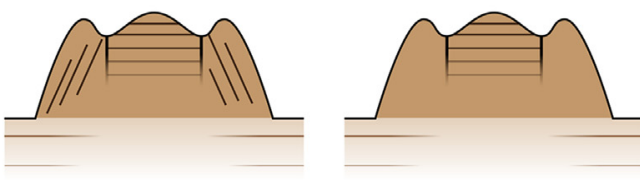

Fig. 4. Illustrations of the facies and corresponding landform morphologies observed in the Candor Colles area. The strata comprising the lower slopes of knobs expressing facies A1 and A2 are conformable with the local bedrock. Conversely, the lower slopes of knobs expressing facies A4 and A5 are superimposed on the bedrock. The material expressing facies A3 is sub-horizontally stratified. Facies A1 and $\mathrm{A} 2$ have a massive and layered central rock mass, respectively. Facies A3 consists entirely of layered rock. Facies A4 and A5 have layered and massive outer slopes, respectively, and both facies have a layered central rock mass. See Fig. 3 for examples of select facies and landforms.

Based on these observations, I have developed a novel facies scheme to document salient stratal geometries of knobs in this area (Fig. 4). This scheme is applied to knobs in other study areas (in subsequent sections) to enable comparisons between study areas and to facilitate interpretations of formation mechanisms. Knobs that have horizontally stratified outer slopes, with layers that are conformable with the subjacent bedrock can have a central mass that is either massive (facies A1) or stratified (facies A2). Knobs with horizontally stratified outer slopes that are nonconformable with the subjacent bedrock exhibit facies A3. Knobs that have outwardly dipping layers within their outer slopes and a horizontally stratified central mass exhibit facies A4. Finally, knobs that have massive bedding within their outer slopes have a central mass that is stratified (facies A5).

Each facies is found at knobs with specific morphologies (Fig. 4). Facies A1 through A3 are only observed at rounded knobs. However, facies A4 through A5 are observed at all morphologic types of knobs - summit depression, raised rim and central mound, and rounded knob.

The Candor Colles are spatially associated with lobate structures, which are commonly $\sim 1$ to $2 \mathrm{~km}$ wide and $\sim 3$ to $5 \mathrm{~km}$ long (Fig. 5). Though some lobate structures rise up to $50 \mathrm{~m}$ above the surrounding terrain in the HRSC DEMs, other lobate structures have no detectable topographic expression in the same DEMs. Each lobate structure typically is in contact with either a knob or an irregularly shaped rock mass that is either massive or poorly stratified. Further, the lobate structures are either massive or have layers that are continuous and parallel to discontinuous and hummocky. Parallel layering is typically observed proximal to the accompanying massive to poorly stratified rock mass and hummocky bedforms commonly observed distal to that rock mass. The lobate materials are darker than and superpose the stratified bedrock. Colluvium shed from the lobate structures is characteristically smooth at HiRISE scale - no clasts greater than $\sim 0.25 \mathrm{~m}$ in diameter detected.

\section{Knobs and rings in Candor Chaos}

Mesas are the most prominent landforms within the central region of Candor Chaos. The mesas are irregularly shaped and most are several hundred meters to a few kilometers in width (Fig. 6A), although several larger mesas exceeding $5 \mathrm{~km}$ in width are also present. The largest mesas are located roughly in the center of the chaos and are separated by troughs that are up to $2 \mathrm{~km}$ wide. Measurements from the HRSC DEMs indicate that the central region of the chaos is $\sim 200$ to $500 \mathrm{~m}$ higher in elevation than its periphery, with the exception of its western margin where the chaos abuts Candor Mensa. Further, the troughs are $\sim 100$ to $200 \mathrm{~m}$ deep. These troughs also partially dissect some of these large mesas. Smaller mesas (less than a few kilometers in width) frequently occur along the outer margins of the chaos.

Exposures of low-albedo stratified rock with parallel layering (hereafter facies B1; Fig. 7) occur within the steep upper slopes of the mesas. Accumulations of low albedo, meter sized or larger boulders, some with associated boulder tracks, occur around the lower slopes of the mesas and along the floors of the troughs. The lower slopes of the mesas and trough floors appear smooth at HiRISE resolution where boulders are not present.

Knobs are interspersed amongst the mesas. The knobs are quasi-circular to irregularly shaped in map view and have basal diameters and long axis lengths of $\sim 0.1$ to $1 \mathrm{~km}$. All of these landforms express the rounded knob morphology (Fig. 7). The knobs rise $\sim 50$ to $150 \mathrm{~m}$ above the surrounding terrain in the HRSC DEMs.

As with the mesas, many rounded knobs exhibit the B1 facies. A few knobs however, have a notably different facies, which is characterized by a significantly higher albedo than the B1 facies (Fig. 6A and B). The slopes of these higher albedo knobs can be either stratified with outward-dipping layers (facies B2) or massive (facies B3). The knobs that express the B2 and B3 facies are similar in size to the knobs expressing the B1 facies. Further, knobs with the B3 facies are observed on the floors of troughs between the large central mesas of Candor Chaos, within the lower slopes of some mesas and amongst the fields of small mesas around the periphery of the chaos.

Interspersed amid the knobs and small mesas, and predominantly along the periphery of Candor Chaos, are distinctive alignments of small hills and sharp-crested ridges. In map view, these hills and ridges form quasi-circular to elliptical rings (Fig. 6C and D). Adjacent rings abut, but do not overlap. The rings have radii and long axis lengths of several hundred meters up to two kilometers. Further, some rings encircle either a single mound or a cluster of mounds (Fig. 6E). Measurements from HRSC DEMs indicate that the crests of the rings are $\sim 10$ to $70 \mathrm{~m}$ tall relative to the surrounding terrain.

The rings exhibit the B2 and B3 facies (Fig. 7). Though some rings uniformly exhibit one of the two facies, examples of both facies can be observed in different portions of most rings. Where facies B2 is observed on abutting rings, some layers can be traced 


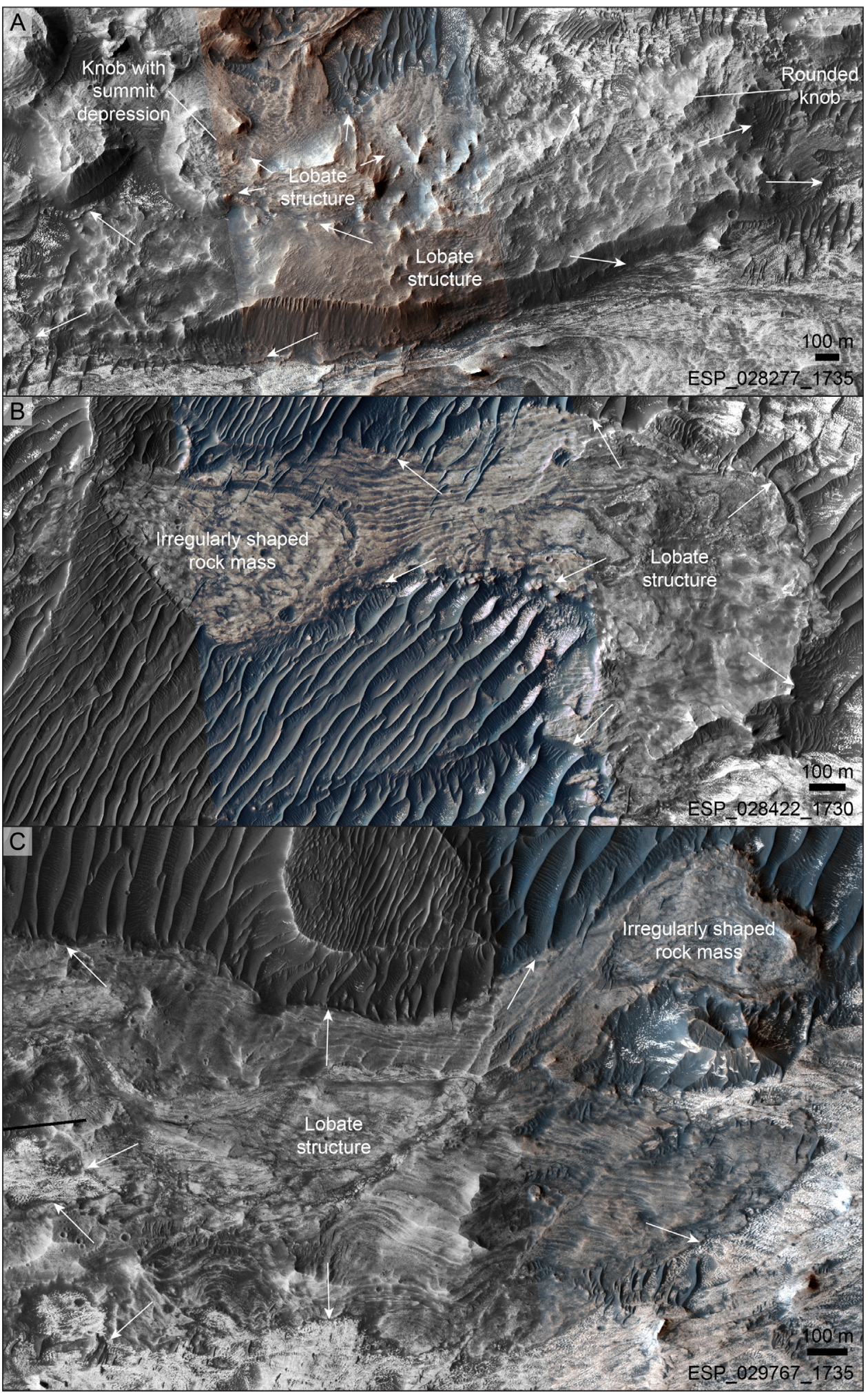

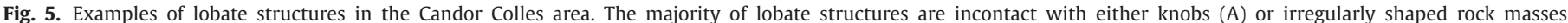
$(B, C)$. Arrows indicate the margins of the lobate structures. These structures unconformably overlie the stratified bedrock, which has a higher albedo.

from one ring to the next. All central mounds encircled by rings appear massive.

Elevation data from the HRSC DEMs show that the mesas are the highest standing landforms in Candor Chaos. The knobs and rings are occasionally as tall as adjacent mesas. More typically however, the peaks of the knobs and rings are tens to a hundred meters lower in elevation than the tops of adjacent mesas.
Low-albedo sand dunes and sand sheets blanket Candor Chaos. These deposits conceal superposition relationships between the bedrock and the rocks that make up the mesas, knobs and rings - thus these superposition relationships have not been determined at this site. The abundant sand also hinders observations of the rock that constitutes these landforms, especially the small mesas, 


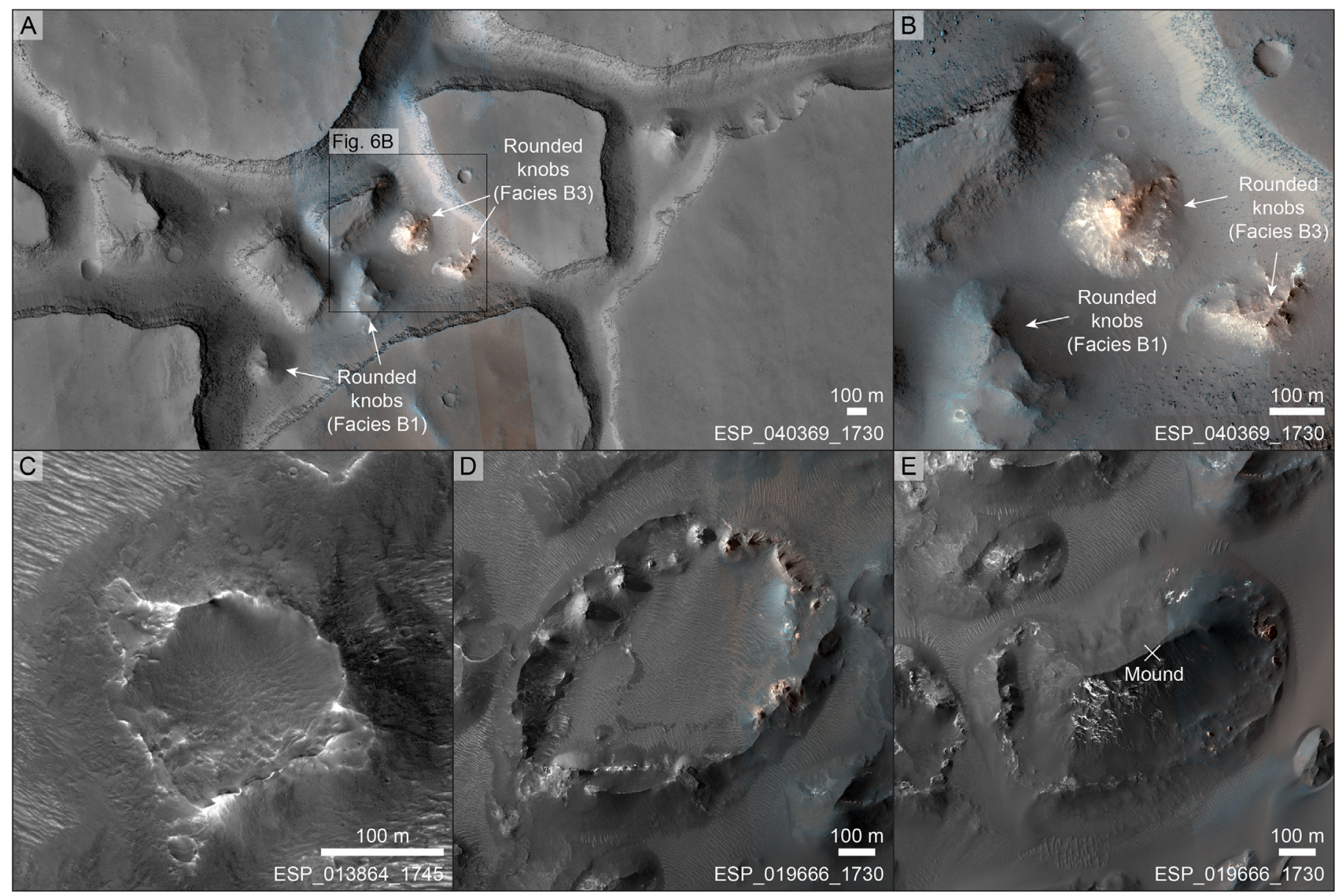

Fig. 6. Examples of landforms and their facies in the Candor Chaos area. (A) Mesas (facies B1) with rounded knobs within the intervening troughs. (B) Rounded knobs exhibiting a low (facies B1) and high (facies B3) albedo. (C) Knob with a summit depression and layered outer slopes (facies B2). (D) Ring with massive outer slopes (facies B3). (E) Ring with a central mound and layered outer slopes (facies B2). See Fig. 2 for image locations. See Fig. 7 for a complete synopsis of the facies observed in the Candor Chaos area.

\section{Facies B1 Facies B2 Facies B3}

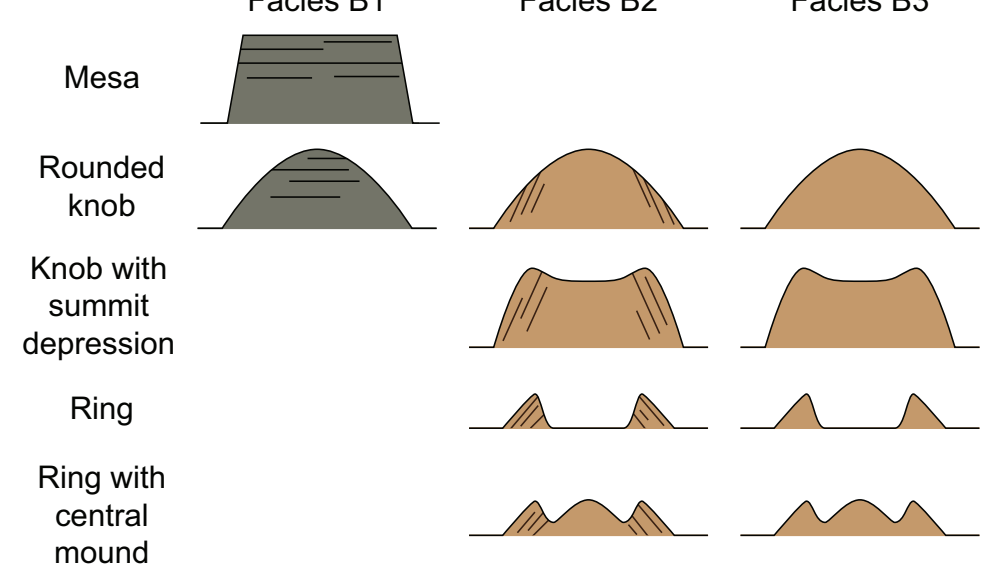

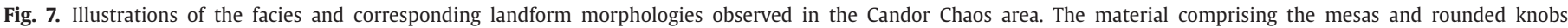

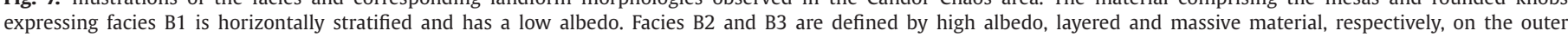
slopes of the associated landforms. See Fig. 6 for examples of select facies and landforms.

knobs and rings. In many cases, facies characterization for each landform is made within small windows between sand deposits.

\section{Knobs and rings in Coprates Chasma}

In map view, the knobs in Coprates Chasma have a quasicircular to irregular outline (Fig. 8). They have basal diameters and long-axis lengths of a few hundred meters to three kilometers. The HRSC DEMs show that the knobs are up to $\sim 350 \mathrm{~m}$ tall. Some knobs are rounded. However, the majority of knobs are topped by one or more summit depressions.

The rounded knobs exhibit a variety of facies (Fig. 9). Some knobs have horizontally stratified outer slopes, with layers that that are conformable with the subjacent bedrock. A few rounded knobs have horizontally stratified slopes that are non-conformable with the subjacent bedrock and no central mass (facies C1; Fig. 8B) that is similar to that observed at the Candor Colles (facies A3). 

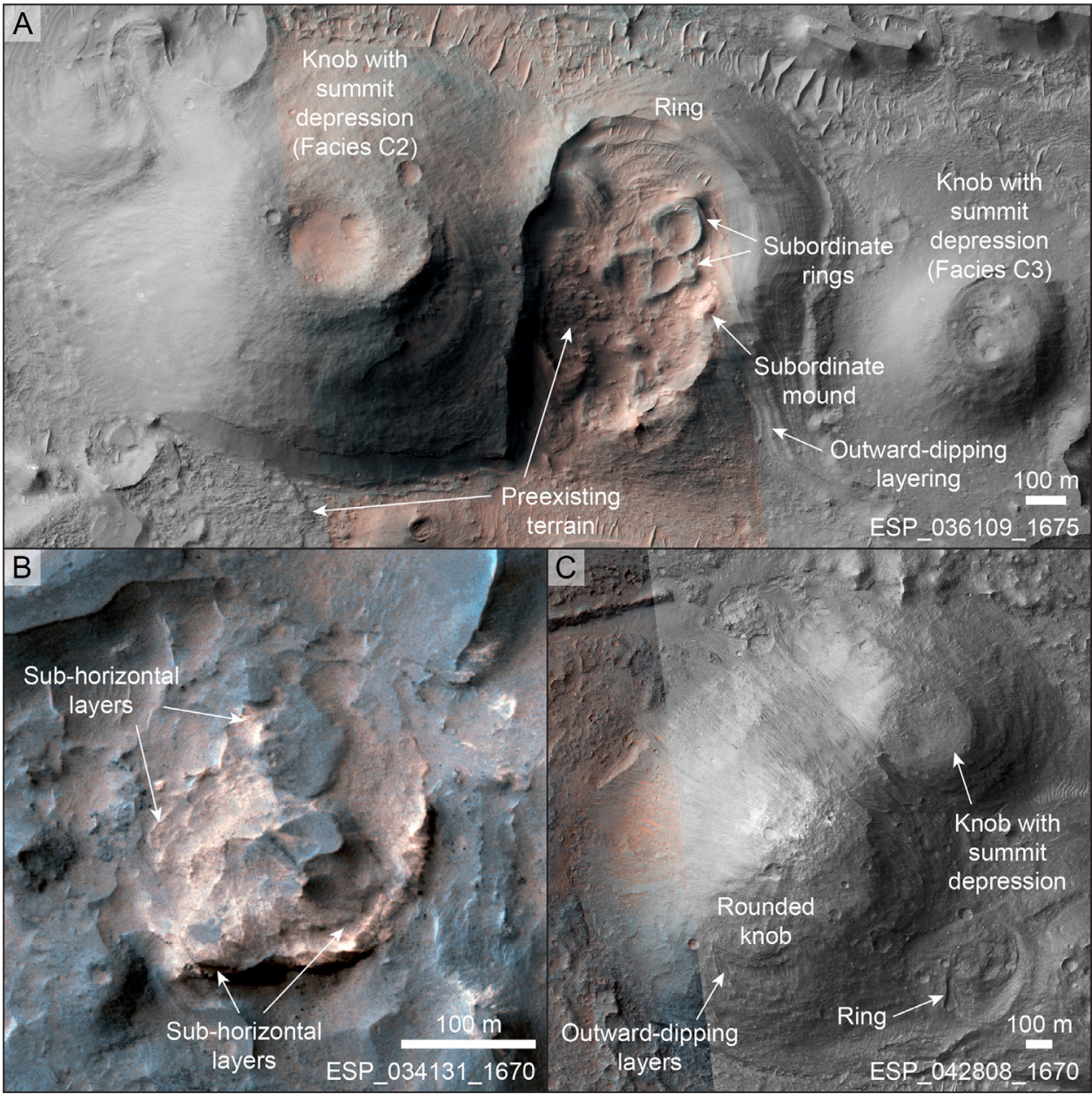

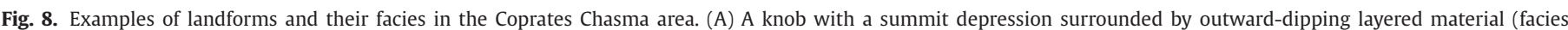

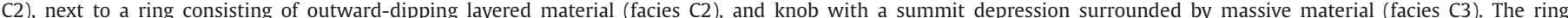

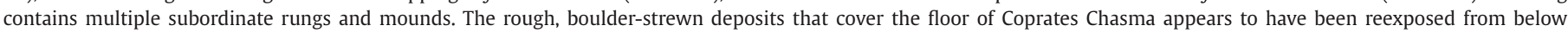

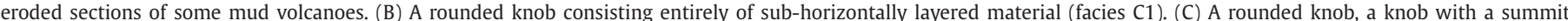

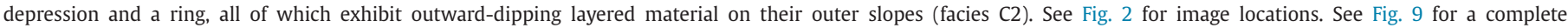
synopsis of the facies observed in the Coprates Chasma area.

Other rounded knobs have outer slopes that are non-conformable with the subjacent bedrock and are either stratified with outward dipping layers (facies C2; Fig. 8C) or are massive (facies C3). Both rounded knob morphologies also do not contain a discernable central mass.

The knobs with summit depressions exhibit either facies $\mathrm{C} 2$ or C3. As with the rounded knobs that express this facies, these knobs have outer slopes that are non-conformable with the subjacent bedrock and do not contain a discernable central mass. None of the knobs with summit depressions exhibit facies C1.

Interspersed amongst the knobs are alignments of small hills and smooth- to sharp-crested ridges. In map view, these hills and ridges form quasi-circular to elliptical rings (Fig. 8A and C). The rings have radii and long axis lengths of a hundred meters up to one kilometer. Measurements from the HRSC DEMs show that the crests of the rings reach up to $\sim 10 \mathrm{~m}$ above the surrounding terrain. The interiors of some rings contain subordinate rings and mounds.

The rings exhibit the $\mathrm{C} 2$ and $\mathrm{C} 3$ facies. Though some rings uniformly exhibit one of the two facies, examples of both facies can be observed in different portions of most rings. Where facies $\mathrm{C} 2$ is observed on abutting rings, some layers can be traced from one ring to the next. The subordinate rings and mounds that occur within larger rings are observed to be either stratified or massive.
For simplicity, these subordinate features are not used to define additional facies.

The knobs and rings are spatially associated with lobate structures that partially or completely encircle some knobs and rings (Fig. 10). Lobate material also occurs as discrete patches within some knobs' summit depressions and within some rings. The lobate structures clearly superpose the knobs and rings in some cases (Fig. 10A). More commonly however, superposition relationships between the lobate structures and adjacent knobs and rings are not evident because there is no clear delineation (e.g., change in surface texture or albedo, break in slope) between the two (Fig. 10B). Some lobate structures have no associated knob or ring. The lobate structures have a smooth to hummocky surface texture. Stratification typically parallels the underlying surface and is occasionally hummocky. Colluvium shed from the lobate structures comprises a mix of smooth sediments (no clasts greater than $\sim 0.25 \mathrm{~m}$ in diameter are visible) to meter-scale clasts.

All of the knobs and rings, as well as the lobate structures, superpose the bedrock. This is most clearly observed around the periphery of these features where some of the constituent materials have been eroded away, exposing the contact with the underlying bedrock. Similarly, the bedrock is exposed within the inner floor of some rings (Fig. 8A). The bedrock has a pitted and boulder-strewn 


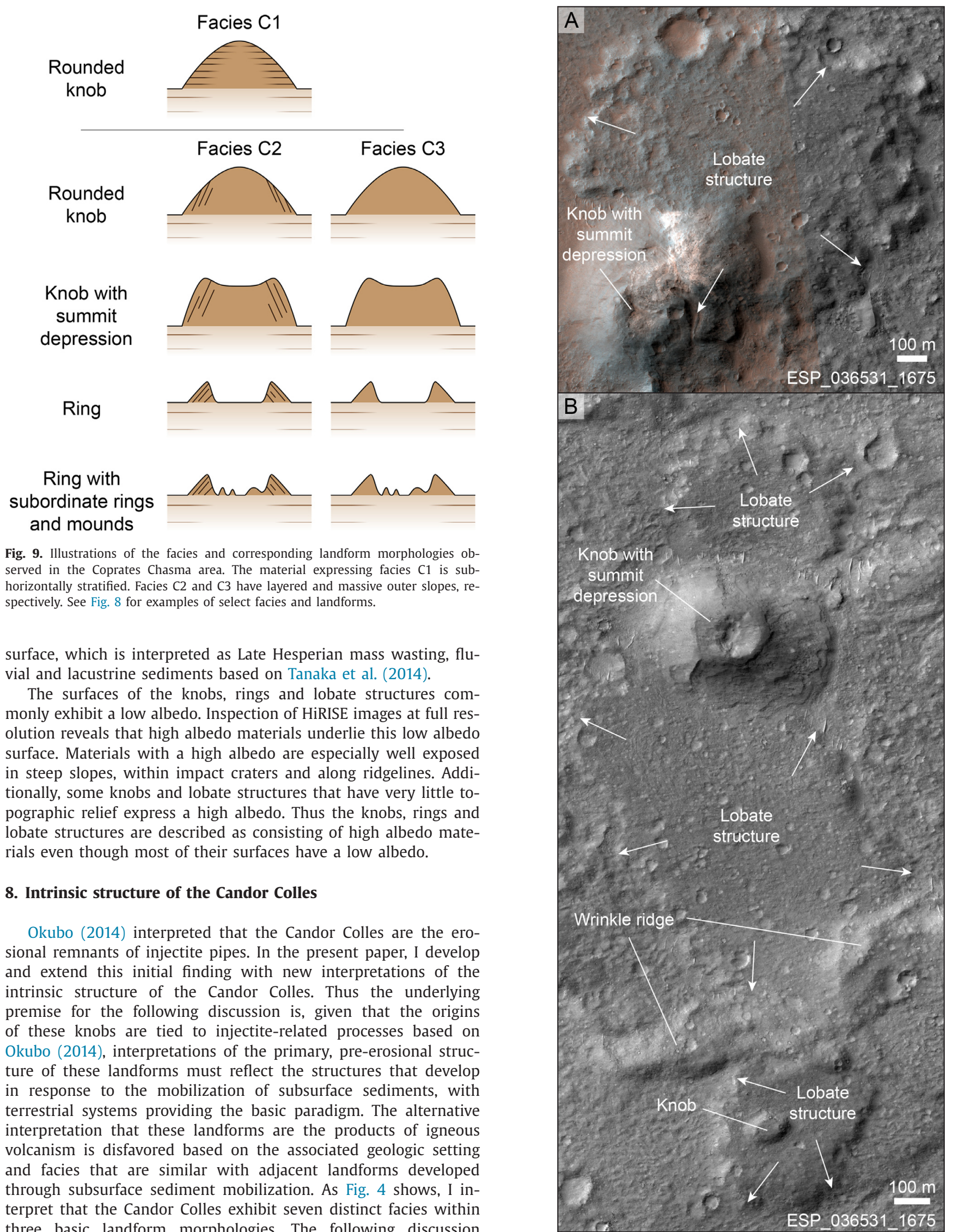

terpret that the Candor Colles exhibit seven distinct facies within three basic landform morphologies. The following discussion presents my interpretations of each landform morphology tied to interpretations of each facies.

In the initial analyses of the Candor Colles, Okubo (2014) interpreted that rounded knobs exhibiting facies A1 and A2 are the
Fig. 10. Examples of lobate structures in the Coprates Chasma area. Arrows indicate the margins of the lobate structures. The majority of lobate structures partially or completely encompass either a knob or ring. (A) A lobate structure superimposed on the associated knob or ring. (B) Examples of ambiguous superposition relationships between the knob and lobate structure due to poorly defined lobe margins. 
erosional remnants of injectite pipes (cf., Netoff and Shroba, 2001). In this interpretation, the massive (facies A1) and stratified (facies A2) central rock masses comprise injectites, while the stratified rock on the flanks of the knobs is the in situ bedrock. The lack of apparent stratification in facies A1 may reflect a massive structure (common to injectites), may be the result of resolution limits in the HiRISE data - textural contrasts may be too low to distinguish between layers or the layers may be too thin to detect, or stratification may be obscured by surficial sediment.

The patterns of stratification expressed in facies A4 and A5 are characteristic of terrestrial mud volcanoes. In terrestrial examples, the outward-dipping layers on the outer slopes of the knobs are mud flows that issued out of a vent generally located in the central, upper regions of the volcano or smaller satellite vents along the flanks (e.g., Davies and Stewart, 2005; Delisle et al., 2002; Hovland et al., 1997; Planke et al., 2003; Stewart and Davies, 2006) (Fig. 1A). These mud flows are unconformable with the underlying bedrock. The vent area is characterized by a rock mass formed by upwelling, extruded and ponded mud, essentially the neck of the mud volcano, with the neck being either massive or stratified (Kholodov, 2002; Roberts et al., 2010).

Terrestrial mud volcanoes also exhibit landform morphologies comparable to those associated with facies A4 through A5 at the Candor Colles (e.g., Kassi et al., 2014; Oppo et al., 2014; Planke et al., 2003; Somoza, 2003; Van Rensbergen, 2005). Terrestrial mud volcanoes that have a summit caldera are morphologically similar to the knobs with summit depressions (Fig. 1A-C). Some terrestrial mud volcanoes also have morphologies akin to the knobs with a raised rim and central mound (Fig. 1B). In this case, the central mound is interpreted to be a dome of mud that was emplaced within the summit caldera. Finally, some terrestrial mud volcanoes resemble rounded knobs. These volcanoes either never developed a summit caldera (Fig. 1D), had their summit caldera completely buried by a central mound or are the eroded remnants of larger mud volcanoes. Most terrestrial mud volcano fields contain a mix of the aforementioned landform morphologies. Based on their facies and morphologic similarities to terrestrial mud volcanoes, and their geologic context, I interpret the landforms that express facies A4 through A5 as mud volcanoes. Further, I interpret the central rock masses to be mud volcano necks.

Some terrestrial mud volcanoes have undergone significant erosion, so much so that much of the mud volcano edifice has been removed. In these cases, the mud volcano necks are all that typically remains (e.g., Kholodov, 2002; Roberts et al., 2010). These necks have a cylindrical to rounded knob shape and are unconformable with the surrounding bedrock. These necks can occur adjacent to mud volcanoes that are active and/or minimally eroded. Based on their morphology, being unconformable with the surrounding bedrock, and their proximity to the previously discussed mud volcanoes (facies A4 and A5), I interpret the rounded knobs that express facies $A 3$ to be either the necks of mud volcanoes that have been largely removed by erosion, or low-relief mud volcanoes that never developed a caldera (Fig. 1D).

With respect to the lobate structures that occur amongst the colles, I also interpret these landforms as the products of mud volcanism, specifically voluminous long mud flows that did not accumulate on a central edifice (e.g., Fig. 1E and F). The continuous and parallel layering within the lobate material arises from multiple superposed mud flows, while the discontinuous and hummocky layering reflects their distal toes. The irregularly shaped, knoblike rock masses are either the mud volcano edifice or the mud volcano neck (exposed by erosion) from which these mud flows were extruded. The observed extent of these mud flows reflect the preexisting topography across which these flows traveled (i.e., flows are preserved in inverted relief) and subsequent patterns of deflation.
Several of these flow fields have been pervasively eroded such that multiple flows (several to tens) have been crosscut and the flow fields currently exhibit little topographic relief above the deflation surface that characterizes the surrounding stratified bedrock (Fig. 5). This pattern of erosion, along with the lack of large $(>0.25 \mathrm{~m}$ ) clasts within the derived colluvium, suggests that the flows are friable, with a competency comparable to the sedimentary bedrock. Such friability is consistent with the mud flow interpretation for these landforms, rather than the alternative lava flow interpretation.

Lava flows are expected to persist through periods of deflation of the sedimentary bedrock in a similar manner to the persistence of the adjacent Ceti Labes (Fig. 2) through multiple episodes of deposition and deflation of the sedimentary bedrock (cf., Okubo, 2014). The Ceti Labes is a landslide deposit of the volcanic rock that comprises the chasma walls, and this landslide predates the sedimentary bedrock from which the Candor Colles were sourced. A notional lava flow in this study area could become friable if it were pervasively weathered through diagenetic or hydrothermal processes. However, the Ceti Labes deposits show no evidence of such alteration (Murchie et al., 2009). Therefore interpretations of the lobate structures as extensively altered basaltic lava flows are not supported by observations.

\section{Origins of landforms in Candor Chaos}

The rounded knob landforms within Candor Chaos are comparable in morphology to those in the Candor Colles (Figs. 3 and 6). The facies B2 and B3 expressed by some rounded knobs are comparable to the Candor Colles' facies A4 and facies A5 respectively. Given that the geologic context of the Candor Chaos is comparable to the Candor Colles (i.e., a depositional basin within Candor Chasma) and that the ages and provenance of the materials are similar (Middle Amazonian mass wasting deposits overlying Hesperian eolian deposits), I propose that the rounded knobs in Candor Chaos that exhibit facies B2 and B3 are analogous to those in Candor Colles. Thus, the rounded knobs are interpreted as mud volcanoes that either have been significantly eroded, had a summit caldera completely in-filled by later mound-building eruptions, or that never developed a summit caldera. As previously proposed for the massive A5 facies in the Candor Colles, the structureless character of facies B3 may be due to a massive primary structure, layering that is too thin to be resolved by HiRISE, or stratification that is obscured by surficial sediment.

The ring and ring-with-central mound landforms observed in Candor Chaos have no direct equivalent in the Candor Colles. Nevertheless, I also interpret these landforms as the products of mud volcanism. Specifically, the rings are interpreted as mud volcanoes that developed around a mud diatreme. Further, the ring with central mound landforms are interpreted as a ring around a mud diatreme that was subsequently superposed by a mound-like mud volcano akin to the rounded knobs observed elsewhere in the Candor Chaos and in the Candor Colles.

These interpretations are based on observations of mud diatremes on Earth. A terrestrial mud diatreme develops through the upward migration and eruption of subsurface mobilized sediments that are more highly pressurized and more fluid-rich than the sediments that form other more mound-like mud volcanoes (Brown, 1990). The ejected muds accumulate as a ring around the venting diatreme (MacDonald and Peccini, 2009; Stoppa, 2006; Yusifov and Rabinowitz, 2004). Diatreme activity can cease and give way to the formation of mound-like mud volcanoes if the erupting sediment becomes clast-rich, with a lower fluid content (Lance et al., 1998; MacDonald and Peccini, 2009).

In addition to the knobs and rings, formation of Candor Chaos' mesas may also be part of a more complex regional system of 
subsurface sediment mobilization. Skinner and Tanaka (2007) noted the occurrence of fractured rises, composed of mesas separated by a network of troughs, in the southern Utopa Planitia region of Mars. They interpreted these rises to be the surface expressions of mud laccoliths. Given that the geologic context of the Candor Chaos and southern Utopia Planitia are similar, in that both are sedimentary depocenters, and that subsurface sediment mobilization is an interpreted processes for both sites based in part on interpretations of mud volcanoes, a mud laccolith origin for the Candor Colles is a reasonable hypothesis. In this proposed scenario, the mesas that comprise Candor Chaos formed in response to the intrusion of a subjacent mud laccolith. Eruption of mud from this laccolith then fed the growth of mud volcanoes within the troughs between the mesas and around the periphery of the chaos. The roughly $80 \mathrm{~km}$ by $60 \mathrm{~km}$ areal extent of the Candor Chaos is well within the size range of the fractured rises studied by Skinner and Tanaka (2007). Therefore the scale of mud volcanism proposed for the Candor Chaos is comparable to the potentially analogous mud volcano systems in Utopia Planitia.

The Hesperian eolian deposits that underlie the Middle Amazonian mass wasting materials (Tanaka et al., 2014) are a likely source of sediments for subsurface sediment mobilization and mud volcanism in the Candor Chaos. This assertion is based on the results from the adjacent Candor Colles, where subsurface mobilized sediments there were derived from these same deposits. Further, the relatively high albedo of facies B2 and B3 is consistent with the albedo of these Hesperian eolian sediments. Further, the mesas and rounded knobs that express facies B1 are interpreted to consist of Middle Amazonian mass wasting materials, which make up uppermost deposits in this part of Candor Chasma (Tanaka et al., 2014).

\section{Origins of the pitted mounds in Coprates Chasma}

The landforms examined in Coprates Chasma express morphologies and facies that are in common with the interpreted injectites and mud volcanoes in the Candor Colles and Candor Chaos (Figs. 3, 6 and 8). The geologic context of the Coprates Chasma landforms is also comparable to that of the mud volcanoes in Candor, because both chasmata are basins filled with Hesperian eolian sediments. Accordingly, I interpret these landforms in Coprates Chasma as either injectites that have been exhumed through erosion or mud volcanoes.

Following the line of reasoning discussed for the rings in the Candor Chaos, the ring landforms in Coprates Chasma are interpreted as mud volcanoes that formed around diatremes. Further, the central mound contained within some rings is interpreted as the result of a change from an initial fluid-rich diatreme-related activity to the secondary eruption of clast-rich muds and the development of mound-like mud volcanoes. The subordinate rings and mounds contained within some rings are interpreted as the result of mud volcanism involving lower fluxes of fluid-rich and clast-rich muds, respectively.

The rounded knobs and knobs with a summit depression that express facies C2 and C3 are interpreted as mud volcanoes, just as with the landforms that express comparable morphologies and facies in Candor Colles (A4 and A5) and Candor Chaos (B2 and B3) (Figs. 4, 7 and 9). The knobs with a summit depression are mud volcanoes that developed a caldera at their summit, and the rounded knobs are mud volcanoes that either have been significantly eroded, had a summit caldera completely in filled by later mound-building eruptions, or that never developed a caldera.

Other rounded knobs are interpreted as exposures of formerly mobilized, subsurface sediments that have been exhumed and exposed through erosion. The rounded knobs that express facies $\mathrm{C} 1$ are interpreted to be the necks of mud volcanoes that have been largely removed by erosion, or low-relief mud volcanoes that never developed a caldera. These landforms are equivalent to the rounded knobs that express facies A3 in the Candor Colles.

In all of the above instances, the massive character of the knobs and rings corresponding to facies $\mathrm{C} 3$ is assumed to be the same as discussed for the massive facies in the Candor Colles (A5) and Candor Chaos (B3). That is, this lack of apparent stratification may reflect a massive primary structure, may be the result of resolution limits in the HiRISE data, or stratification may be obscured by surficial sediment.

Further, I interpret the lobate materials associated with some knobs and rings as accumulations of voluminous long mud flows, similar to the lobate structures in Candor Colles. Some of these flows can be clearly traced back to a source within a mud volcano caldera, while other flows have no clear source area. The mud flows in the Coprates Chasma area are generally less eroded than those in the Candor Colles, and therefore the internal structure of the Coprates flow fields is rarely exposed.

Erosional exposures of the Late Hesperian mass wasting, fluvial and lacustrine sediments below the mud volcanoes (Fig. 8A) indicate that sediment mobilization occurred during the Late Hesperian or later. The Hesperian eolian deposits that are buried below the Late Hesperian sediments (cf., Tanaka et al., 2014) are the likely source of sediment for these mud volcanoes and flows. Finegrained sediments from within the Late Hesperian surficial sediments may also contribute to the erupted muds.

\section{Discussion}

The landforms discussed in this paper stand apart from most putative mud volcanoes previously studied elsewhere in their degree of exposure, lithology, and knowledge of their geologic context. Several factors allow particularly confident interpretations to be made here. The landforms discussed here have experienced varied degrees of incision and erosion. This enables examination of the landforms' morphologies relative to their internal structure, as well as superposition and crosscutting relationships amongst the landforms and with the bedrock. These are novel observations that facilitate new interpretations of the landforms' formation mechanism. Further, the material that comprises these landforms exhibits a significantly higher albedo than the local surficial sediments. This helps to clearly delineate the materials that comprise the bulk of the landform from the mantle of surficial sediments, which may or may not be relevant to the landforms' formation mechanism. Such a distinction is not always clear in other areas, where the putative mud volcanoes consist of material with a low albedo similar to the local surficial sediments. In those examples, the separation between the landforms' intrinsic internal structure and potentially unrelated surficial sediments is muddled. Finally, the work of Okubo (2014) established the existence of injectite pipes in the Candor Colles and reconstructed the local geologic history, including the possible timing of subsurface sediment mobilization. These observations and interpretations establish a geologic context for investigations of the adjacent, contemporaneous and morphologically similar landforms that are the subject of this paper.

I do not favor the interpretation of these landforms as the products of igneous volcanism because (1) the associated geologic settings are sedimentary depocenters, (2) these landforms exhibit the structure and facies that are comparable to features previously interpreted as the products of subsurface sediment mobilization (i.e., the Candor Colles and terrestrial mud volcanoes), (3) these landforms comprise material with an albedo consistent with the subjacent sedimentary bedrock, which is much higher than the adjacent rocks of known volcanic origin (chasma wall rock and derived mass wasting deposits), and (4) the associated lobate flows are as friable as the sedimentary bedrock, both of which 
are much more easily eroded (deflated) than the adjacent volcanic rocks. Though such geologic associations do not completely rule out an igneous origin for these landforms, they provide a strong counter-argument that is based on novel high-resolution observations and results of recent large-scale geologic mapping. Additional large-scale geologic mapping of these features will help to test interpretations of igneous versus mud volcanic origins.

The injectites and mud volcanoes discussed here necessitate near-surface ground water in the Candor Colles, Candor Chaos and central Coprates Chasma regions of Valles Marineris concurrent with sediment mobilization. Formation of the Candor Colles and deposition of the local stratified sediments occurred contemporaneously (Okubo, 2014), and therefore groundwater would have been present here during the Hesperian (i.e., the age of the local sediments based on Tanaka et al. (2014)). Elsewhere in Candor Chasma, mud volcanism crosscuts the Middle Amazonian mass wasting deposits that cap the mesas of the Candor Chaos, signifying relatively recent groundwater activity during the Amazonian. In central Coprates Chasma, the mud volcanoes are contemporaneous with or post-date Late Hesperian sediments, signifying groundwater activity during the Late Hesperian to Early Amazonian.

\section{Future work}

The observations and interpretations presented here provide testable predictions and corollaries for the proposed mud volcanoes and their surroundings. A key prediction of this work is that the mud volcanoes and flows should have a sulfate composition similar to the Hesperian eolian deposits that I propose to be the source of these muds. Since terrestrial mud volcanoes are sites of persistent groundwater activity, the mud volcanoes and flows on Mars also may contain evidence of diagenesis, such as an elevated iron oxide (or other precipitates) content relative to the pristine source rock composition. These predictions can be tested with targeted observations by the Compact Reconnaissance Imaging Spectrometer for Mars (CRISM). With only two targeted observations of these features in Valles Marineris, CRISM coverage is currently insufficient to support a systematic investigation into their composition.

In addition to the Candor Chaos, several other areas resembling the fractured rises of Skinner and Tanaka (2007) are present within the Valles Marineris region. Examples include Baetis, Eos and Ganges Chaoses, and other unnamed fractured-rise-like terrain in Noctis Labyrinthus and east Candor Chasma. These and other chaoses across Mars require a new suite of investigations testing for evidence of chaos formation through subsurface sediment mobilization and mud volcanism. Additionally, since Skinner and Tanaka (2007) interpret the fractured rises to have formed through mud diapirism, adjacent stratified sediments may show evidence of post-depositional folding and uplift if sedimentation predates mud diapirism - preliminary large-scale geologic mapping suggests this to be the case for sediments onlapping the possible fractured rise shown in Fig. 2 in east Candor Chasma (Okubo and Edgar, 2015).

Finally, investigations into mud volcanism on Mars will greatly benefit from the development of morphometric criteria that can be used to more rigorously distinguish between the products of mud and igneous volcanism. These criteria need to be sufficiently rooted in the mechanics of mud and igneous volcanism on Earth to enable a systematic adaptation of the morphometric criteria to the Martian environment. Such work would be a significant undertaking involving field observations, theoretical considerations and numerical modeling. However, the abundance of proposed mud volcanoes on Mars and the astrobiologic potential of these landforms provide a compelling rationale for such work.

\section{Conclusions}

Populations of knobs, rings and lobate structures in the Candor Colles, Candor Chaos and in Coprates Chasma regions of Valles Marineris are interpreted as mud volcanoes, exhumed injectites and mud flows based on their facies, morphologies, superposition and cross-cutting relationships. The source of sediment for this mud volcanism is interpreted to be the Hesperian eolian deposits that fill Valles Marineris. Groundwater upwelling during the Hesperian to possibly the Early Amazonian is interpreted to have facilitated subsurface mobilization of sediments and the resulting mud volcanism. Though this paper focused on only three study areas, available HiRISE images reveal numerous examples of landforms with similar morphologies and facies throughout Valles Marineris. Therefore subsurface sediment mobilization and mud volcanism appears to have been important process in this region during the Hesperian. Finally, the proposed causal relationship between subsurface sediment mobilization and formation of Candor Chaos provides impetus for future investigations of mud volcanism in other chaotic terrains in the Valles Marineris regions.

\section{Acknowledgments}

C. Dundas, R. Hayward, J. Richie, and J. Skinner, provided thoughtful and helpful comments as part of the USGS internal review of this paper (IP-069444). Two anonymous external reviewers also helped to clarify and strengthen the content of this work. Any use of trade, firm, or product names is for descriptive purposes only and does not imply endorsement by the U.S. Government. This material is based upon work supported by the National Aeronautics and Space Administration under Agreement nos. NNH10AN96I, NNH11AQ101 and NNH14AX991 issued through the Science Mission Directorate.

\section{Supplementary materials}

Supplementary material associated with this article can be found, in the online version, at doi:10.1016/j.icarus.2015.12.051.

\section{References}

Alain, K., Holler, T., Musat, F., et al., 2006. Microbiological investigation of methaneand hydrocarbon-discharging mud volcanoes in the Carpathian Mountains, Romania. Environ. Microbiol. 8, 574-590. doi:10.1111/j.1462-2920.2005.00922.x.

Andrews-Hanna, J.C., 2012a. The formation of Valles Marineris: 1. Tectonic architecture and the relative roles of extension and subsidence. J. Geophys. Res.: Planets 117, E03006. doi:10.1029/2011je003953.

Andrews-Hanna, J.C., 2012b. The formation of Valles Marineris: 2. Stress focusing along the buried dichotomy boundary. J. Geophys. Res.: Planets 117, E04009. doi:10.1029/2011je003954

Andrews-Hanna, J.C., 2012c. The formation of Valles Marineris: 3. Trough formation through super-isostasy, stress, sedimentation, and subsidence. J. Geophys. Res.: Planets 117, E06002. doi:10.1029/2012je004059.

Andrews-Hanna, J.C., Lewis, K.W., 2011. Early Mars hydrology: 2. Hydrological evolution in the Noachian and Hesperian epochs. J. Geophys. Res. 116, E02007. doi:10.1029/2010JE003709.

Andrews-Hanna, J.C., Zuber, M.T., Arvidson, R.E., et al., 2010. Early Mars hydrology: Meridiani playa deposits and the sedimentary record of Arabia Terra. J. Geophys. Res. 115, E06002. doi:10.1029/2009je003485.

Baioni, D., 2013. Morphology and geology of an interior layered deposit in the western Tithonium Chasma, Mars. Planet. Space Sci. 89, 140-150. doi:10.1016/j.pss. 2013.09.019.

Baioni, D., Wezel, F.C., 2010. Morphology and origin of an evaporitic dome in the eastern Tithonium Chasma, Mars. Planet. Space Sci. 58, 847-857. doi:10.1016/j. pss.2010.01.009.

Bibring, J.-P., Langevin, Y., Mustard, J.F., et al., 2006. Global mineralogical and aqueous Mars history derived from OMEGA/Mars express data. Science 312, 400 404. doi:10.1126/science.1122659.

Bridges, J.C., Seabrook, A.M., Rothery, D.A., et al., 2003. Selection of the landing site in Isidis Planitia of Mars probe Beagle 2. J. Geophys. Res. 108, 5001. doi:10.1029/ 2001JE001820.

Brown, K.M., 1990. The nature and hydrogeologic significance of mud diapirs and diatremes for accretionary systems. J. Geophys. Res. 95, 8969-8982. doi:10.1029/ JB095iB06p08969. 
Brož, P., Čadek, O., Hauber, E., et al., 2015. Scoria cones on Mars: Detailed investigation of morphometry based on high-resolution digital elevation models. J. Geophys. Res.: Planets 120, 1512-1527. doi:10.1002/2015JE004873.

Campbell, K.A., 2006. Hydrocarbon seep and hydrothermal vent paleoenvironments and paleontology: Past developments and future research directions. Palaeogeogr. Palaeoclimatol. Palaeoecol. 232, 362-407. doi:10.1016/j.palaeo.2005.06. 018.

Cavagna, S., Clari, P., Martire, L., 1999. The role of bacteria in the formation of cold seep carbonates: Geological evidence from Monferrato (Tertiary, NW Italy). Sediment. Geol. 126, 253-270. doi:10.1016/S0037-0738(99)00044-5.

Chan, M.A., Netoff, D.I., Blakey, R.C., et al., 2007. Clastic-injection pipes and syndepositional deformation structures in Jurassic eolian deposits: Examples from the Colorado Plateau. In: Hurst, A., Cartwright, J. (Eds.), Sand injectites: Implications for hydrocarbon exploration and production, 87. AAPG Memoir, pp. 233-244.

Chan, M.A., Ormö, J., Murchie, S., et al., 2010. Geomorphic knobs of Candor Chasma, Mars: New Mars Reconnaissance Orbiter data and comparisons to terrestrial analogs. Icarus 205, 138-153.

Chapman, M.G., Tanaka, K.L., 2002. Related magma-ice interactions: Possible origins of Chasmata, Chaos, and surface materials in Xanthe, Margaritifer, and Meridiani Terrae, Mars. Icarus 155, 324-339. doi:10.1006/icar.2001.6735.

Chapman, M.G., Tanaka, K.L., 2001. Interior trough deposits on Mars: Subice volcanoes? J. Geophys. Res. 106, 10087-10100. doi:10.1029/2000je001303.

Clari, P., Dela Pierre, F., Martire, L., et al., 2009. The Cenozoic $\mathrm{CH}_{4}$-derived carbonates of Monferrato (NW Italy): A solid evidence of fluid circulation in the sedimentary column. Mar. Geol. 265, 167-184. doi:10.1016/j.margeo.2009.07.007.

Davies, R.J., Stewart, S.A., 2005. Emplacement of giant mud volcanoes in the South Caspian Basin: 3D seismic reflection imaging of their root zones. J. Geol. Soc. 162, 1-4. doi:10.1144/0016-764904-082.

de Pablo, M., Komatsu, G., 2009. Possible pingo fields in the Utopia basin, Mars: Geological and climatical implications. Icarus 199, 49-74. doi:10.1016/j.icarus. 2008.09.007.

Delisle, G., Von Rad, U., Andruleit, H., et al., 2002. Active mud volcanoes on- and offs-hore eastern Makran, Pakistan. Int. J. Earth Sci. 91, 93-110. doi:10.1007/ s005310100203.

Deville, E., Guerlais, S.-H., Callec, Y., et al., 2006. Liquefied vs stratified sediment mobilization processes: Insight from the South of the Barbados accretionary prism. Tectonophysics 428, 33-47. doi:10.1016/j.tecto.2006.08.011.

Dimitrov, L.I., 2002. Mud volcanoes-the most important pathway for degassing deeply buried sediments. Earth-Sci. Rev. 59, 49-76. doi:10.1016/S0012-8252(02) 00069-7.

Dohm, J.M., Hare, T.M., Robbins, S.J., et al., 2015. Geological and hydrological histories of the Argyre province, Mars. Icarus 253, 66-98. doi:10.1016/j.icarus.2015. 02.017.

Dundas, C.M., Mellon, M.T., McEwen, A.S., et al., 2008. HiRISE observations of fractured mounds: Possible Martian pingos. Geophys. Res. Lett. 35, L04201. doi:10. 1029/2007GL031798.

Farrand, W.H., 2005. Pitted cones and domes on Mars: Observations in Acidalia Planitia and Cydonia Mensae using MOC, THEMIS, and TES data. J. Geophys. Res. 110, E05005. doi:10.1029/2004JE002297.

Folk, R.L., 1954. The distinction between grain size and mineral composition in sedimentary-rock nomenclature. J. Geol. 62, 344-359.

Franchi, F., Rossi, A.P., Pondrelli, M., et al., 2014. Geometry, stratigraphy and evidences for fluid expulsion within Crommelin crater deposits, Arabia Terra, Mars. Planet. Space Sci. 92, 34-48. doi:10.1016/j.pss.2013.12.013.

Frey, H., Jarosewich, M., 1982. Subkilometer Martian volcanoes: Properties and possible terrestrial analogs. J. Geophys. Res. 87, 9867-9879. doi:10.1029/ JB087iB12p09867.

Frey, H., Lowry, B.L., Chase, S.A., 1979. Pseudocraters on Mars. J. Geophys. Res. 84, 8075-8086. doi:10.1029/JB084iB14p08075.

Frey-Martinez, J., Cartwright, J., Hall, B., et al., 2007. Clastic Intrusion at the Base of Deep-water Sands: A Trap-forming Mechanism in the Eastern Mediterranean. In: Hurst, A., Cartwright, J. (Eds.), Sand injectites: Implications for hydrocarbon exploration and production, 87. AAPG Memoir, pp. 49-63. doi:10.1306/ 1209849M873255.

Fueten, F., Flahaut, J., Le Deit, L., et al., 2011. Interior layered deposits within a perched basin, southern Coprates Chasma, Mars: Evidence for their formation, alteration, and erosion. J. Geophys. Res.: Planets 116, E02003. doi:10.1029/ 2010je003695

Fueten, F., Flahaut, J., Stesky, R., et al., 2014. Stratigraphy and mineralogy of Candor Mensa, West Candor Chasma, Mars: Insights into the geologic history of Valles Marineris. J. Geophys. Res.: Planets 119, 331-354. doi:10.1002/2013JE004557.

Fueten, F., Stesky, R.M., MacKinnon, P., 2005. Structural attitudes of large scale layering in Valles Marineris, Mars, calculated from Mars Orbiter Laser Altimeter data and Mars Orbiter Camera imagery. Icarus 175, 68-77. doi:10.1016/j.icarus.2004. 11.010

Fueten, F., Stesky, R.M., MacKinnon, P., et al., 2008. Stratigraphy and structure of interior layered deposits in west Candor Chasma, Mars, from High Resolution Stereo Camera (HRSC) stereo imagery and derived elevations. J. Geophys. Res. 113, E10008. doi:10.1029/2007JE003053.

Galli, P., 2000. New empirical relationships between magnitude and distance for liquefaction. Tectonophysics 324, 169-187. doi:10.1016/S0040-1951(00)00118-9.

Green-Saxena, A., Feyzullayev, A., Hubert, C.R.J., et al., 2012. Active sulfur cycling by diverse mesophilic and thermophilic microorganisms in terrestrial mud volcanoes of Azerbaijan. Environ. Microbiol. 14, 32713286.
Grotzinger, J.P., Sumner, D.Y., Kah, L.C., et al., 2014. A habitable fluvio-lacustrine environment at Yellowknife Bay, Gale crater, Mars. Science 343, 1242777. doi:10. $1126 /$ science.1242777.

Hovland, M., Hill, A., Stokes, D., 1997. The structure and geomorphology of the Dashgil mud volcano, Azerbaijan. Geomorphology 21, 1-15. doi:10.1016/ S0169-555X(97)00034-2.

Hurst, A., Cartwright, J.A., 2007. Sand Injectites: Implications for Hydrocarbon Exploration and Production, 87. AAPG Memoir, pp. 233-244.

Huuse, M., Cartwright, J., Hurst, A., et al., 2007. Seismic Characterization of Largescale Sandstone Intrusions. In: Hurst, A., Cartwright, J. (Eds.), Sand injectites: mplications for hydrocarbon exploration and production, 87. AAPG Memoir, pp. 21-35. doi:10.1306/1209847M873253.

Huuse, M., Jackson, C.A.-L., Van Rensbergen, P., et al., 2010. Subsurface sediment remobilization and fluid flow in sedimentary basins: An overview. Basin Res 22. 342-360. doi:10.1111/j.1365-2117.2010.00488.x.

Hynek, B.M., Phillips, R.J., Arvidson, R.E., 2003. Explosive volcanism in the Tharsis region: Global evidence in the Martian geologic record. J. Geophys. Res. 108, 5111. doi:10.1029/2003je002062.

Ivanov, M.A., Hiesinger, H., Erkeling, G., et al., 2015. Evidence for large reservoirs of water/mud in Utopia and Acidalia Planitiae on Mars. Icarus 248, 383-391. doi:10.1016/j.icarus.2014.11.013.

Ivanov, M.A., Hiesinger, H., Erkeling, G., et al., 2014. Mud volcanism and morphology of impact craters in Utopia Planitia on Mars: Evidence for the ancient ocean. Icarus 228, 121-140. doi:10.1016/j.icarus.2013.09.018.

Jaumann, R., Neukum, G., Behnke, T., et al., 2007. The high-resolution stereo camera (HRSC) experiment on Mars Express: Instrument aspects and experiment conduct from interplanetary cruise through the nominal mission. Planet. Space Sci. 55, 928-952. doi:10.1016/j.pss.2006.12.003.

Jonk, R., 2010. Sand-rich injectites in the context of short-lived and long-lived fluid flow. Basin Res. 22, 603-621. doi:10.1111/j.1365-2117.2010.00471.x.

Kassi, A.M., Khan, S.D., Bayraktar, H., et al., 2014. Newly discovered mud volcanoes in the Coastal Belt of Makran, Pakistan-Tectonic implications. Arab. J. Geosci. 4899-4909. doi:10.1007/s12517-013-1135-7.

Kholodov, V., 2002. Mud volcanoes, their distribution regularities and genesis: Communication 1. Mud volcanic provinces and morphology of mud volcanoes. Lithol. Miner. Resour. 37, 293-309.

Kokoschka, S., Dreier, A., Romoth, K., et al., 2015. Isolation of Anaerobic Bacteria from terrestrial mud volcanoes (Salse di Nirano, Northern Apennines, Italy). Geomicrobiol. J. 32, 355-364. doi:10.1080/01490451.2014.940632.

Komatsu, G., Ori, G.G., Cardinale, M., et al., 2011. Roles of methane and carbon dioxide in geological processes on Mars. Planet. Space Sci. 59, 169-181. doi:10.1016 j.pss.2010.07.002

Komatsu, G., Ori, G.G., Ciarcelluti, P., et al., 2004. Interior layered deposits of Valles Marineris, Mars: Analogous subice volcanism related to Baikal Rifting, Southern Siberia. Planet. Space Sci. 52, 167-187. doi:10.1016/j.pss.2003.08.003.

Kopf, A.J., 2002. Significance of mud volcanism. Rev. Geophys. 40, 2-1-2-52. doi:10. 1029/2000RG000093

Lance, S., Henry, P., Le Pichon, X., et al., 1998. Submersible study of mud volcanoes seaward of the Barbados accretionary wedge: Sedimentology, structure and rheology. Mar. Geol. 145, 255-292. doi:10.1016/S0025-3227(97)00117-5.

Lanz, J.K., Wagner, R., Wolf, U., et al., 2010. Rift zone volcanism and associated cinder cone field in Utopia Planitia, Mars. J. Geophys. Res. 115, E12019. doi:10.1029/ 2010JE003578.

Lazar, C.S., Parkes, R.J., Cragg, B.A., et al., 2011. Methanogenic diversity and activity in hypersaline sediments of the centre of the Napoli mud volcano, Eastern Mediterranean Sea. Environ. Microbiol. 13, 2078-2091. doi:10.1111/j.1462-2920. 2011.02425.x

Lonergan, L., Cartwright, J.A., 1999. Polygonal faults and their influence on deepwater sandstone reservoir geometries, Alba Field, United Kingdom central North Sea. AAPG Bull. 83, 410-432.

Lucchitta, B.K., 1999. Geologic Map of Ophir and Central Candor Chasmata (MTM05072) of Mars. Geological Investigations Series I-2568. U.S. Geological Survey.

Lucchitta, B.K., 1990. Young volcanic deposits in the Valles Marineris, Mars? Icarus 86, 476-509. doi:10.1016/0019-1035(90)90230-7.

Lucchitta, B.K., Isbell, N.K., Howington-Kraus, A., 1994. Topography of Valles Marineris: Implications for erosional and structural history. J. Geophys. Res. Planets 99, 3783-3798. doi:10.1029/93je03095.

Lucchitta, B.K., McEwen, A.S., Clow, G.D., et al., 1992. The canyon system on Mars Mars 1, 453-492.

MacDonald, I.R., Peccini, M.B., 2009. Distinct activity phases during the recent geologic history of a Gulf of Mexico mud volcano. Mar. Pet. Geol. 26, 1824-1830. doi:10.1016/j.marpetgeo.2008.12.005.

Malin, M.C., Bell III, J.F., Cantor, B.A., et al., 2007. Context Camera Investigation on board the Mars Reconnaissance Orbiter. J. Geophys. Res. 112, E05S04. doi:10. 1029/2006je002808.

Mangold, N., Gendrin, A., Gondet, B., et al., 2008. Spectral and geological study of the sulfate-rich region of West Candor Chasma, Mars. Icarus 194, 519-543. doi:10.1016/j.icarus.2007.10.021

Mazzini, A., Svensen, H., Akhmanov, G.G., et al., 2007. Triggering and dynamic evolution of the LUSI mud volcano, Indonesia. Earth Planet. Sci. Lett. 261, 375-388. doi:10.1016/j.epsl.2007.07.001

McCauley, J.F., Carr, M.H., Cutts, J.A., et al., 1972. Preliminary mariner 9 report on the geology of Mars. Icarus 17, 289-327. doi:10.1016/0019-1035(72)90003-6.

McEwen, A.S., Banks, M.E., Baugh, N.F., et al., 2010. The High Resolution Imaging Science Experiment (HiRISE) during MRO's primary science phase (PSP). Icarus 205, 2-37. 
McGowan, E.M., 2011. The Utopia/Isidis overlap: Possible conduit for mud volcanism on Mars. Icarus 212, 622-628. doi:10.1016/j.icarus.2011.01.025.

Metz, J.M., Grotzinger, J.P., Mohrig, D., et al., 2009. Sublacustrine depositional fans in southwest Melas Chasma. J. Geophys. Res. 114, E10002. doi:10.1029/ 2009je003365.

Michalski, J.M., Niles, P.B., 2012. Atmospheric origin of Martian interior layered deposits: Links to climate change and the global sulfur cycle. Geology 40, 419-422. doi: $10.1130 / \mathrm{g} 32971.1$

Milkov, A., 2000. Worldwide distribution of submarine mud volcanoes and associated gas hydrates. Mar. Geol. 167, 29-42. doi:10.1016/S0025-3227(00)00022-0.

Milkov, A.V., 2003. Global gas flux from mud volcanoes: A significant source of fossil methane in the atmosphere and the ocean. Geophys. Res. Lett. 30, 1037. doi:10. 1029/2002GL016358.

Murchie, S., Roach, L., Seelos, F., et al., 2009. Evidence for the origin of layered deposits in Candor Chasma, Mars, from mineral composition and hydrologic modeling. J. Geophys. Res. E: Planets 114, E00D05. doi:10.1029/2009JE003343.

Netoff, D.I., Shroba, R.R., 2001. Conical sandstone landforms cored with clastic pipes in Glen Canyon National Recreation Area, southeastern Utah. Geomorphology 39, 99-110. doi:10.1016/s0169-555x(00)00096-9.

Oehler, D.Z., Allen, C.C., 2012. Giant polygons and mounds in the lowlands of Mars: Signatures of an ancient ocean? Astrobiology 12, 601-615. doi:10.1089/ast.2011. 0803.

Oehler, D.Z., Allen, C.C., 2010. Evidence for pervasive mud volcanism in Acidalia Planitia, Mars. Icarus 208, 636-657. doi:10.1016/j.icarus.2010.03.031.

Okubo, C.H., 2014. Bedrock Geologic and Structural Map Through the Western Candor Colles Region of Mars. Scientific Investigation Map 3309. U.S. Geological Survey doi: $10.3133 / \operatorname{sim} 3309$

Okubo, C.H., 2010. Structural geology of Amazonian-aged layered sedimentary deposits in southwest Candor Chasma, Mars. Icarus 207, 210-225. doi:10.1016/j. icarus.2009.11.012.

Okubo, C.H., Edgar, L.A., 2015. Early results of large-scale geologic mapping in east Candor Chasma. In: Proceedings of the AGU Fall Meeting 2015. San Francisco, CA.

Olu-Le Roy, K., Sibuet, M., Fiala-Médioni, A., et al., 2004. Cold seep communities in the deep eastern Mediterranean Sea: Composition, symbiosis and spatial distribution on mud volcanoes. Deep Sea Res. Part I: Oceanogr. Res. Pap. 51, 19151936. doi:10.1016/j.dsr.2004.07.004.

Oppo, D., Capozzi, R., Nigarov, A., et al., 2014. Mud volcanism and fluid geochemistry in the Cheleken peninsula, western Turkmenistan. Mar. Pet. Geol. 57, 122-134. doi:10.1016/j.marpetgeo.2014.05.009.

Pachiadaki, M., Kallionaki, A., Dählmann, A., et al., 2011. Diversity and spatial distribution of prokaryotic communities along a sediment vertical profile of a deepsea mud volcano. Microb. Ecol. 62, 655-668. doi:10.1007/s00248-011-9855-2.

Peulvast, J.P., Masson, P.L., 1993. Erosion and tectonics in Central Valles Marineris (Mars): A new morpho-structural model. Earth Moon Planets 61, 191-217. doi:10.1007/bf00572245.

Planke, S., Svensen, H., Hovland, M., et al., 2003. Mud and fluid migration in active mud volcanoes in Azerbaijan. Geo-Mar. Lett. 23, 258-267. doi:10.1007| s00367-003-0152-z.

Pondrelli, M., Rossi, A.P., Ori, G.G., et al., 2011. Mud volcanoes in the geologic record of Mars: The case of Firsoff crater. Earth Planet. Sci. Lett. 304, 511-519. doi:10. 1016/j.epsl.2011.02.027.

Poulet, F., Bibring, J.-P., Mustard, J.F., et al., 2005. Phyllosilicates on Mars and implications for early martian climate. Nature 438, 623-627.

Quantin, C., 2005. Fluvial and lacustrine activity on layered deposits in Melas Chasma, Valles Marineris, Mars. J. Geophys. Res. 110, E12S19. doi:10.1029/ 2005JE002440

Roberts, K.S., Davies, R.J., Stewart, S.A., 2010. Structure of exhumed mud volcano feeder complexes, Azerbaijan. Basin Res. 22, 439-451. doi:10.1111/j.1365-2117. 2009.00441.x

Rossi, A.P., Neukum, G., Pondrelli, M., et al., 2008. Large-scale spring deposits on Mars? J. Geophys. Res. 113, E08016. doi:10.1029/2007JE003062.
Schultz, R.A., 1998. Multiple-process origin of Valles Marineris basins and troughs, Mars. Planet. Space Sci. 46, 827-834. doi:10.1016/S0032-0633(98)00030-0.

Scott, D.H., Tanaka, K.L., 1986. Geologic Map of the Western Equatorial Region of Mars. U.S. Geological Survey Miscellaneous Investigations Series Map I-1802A.

Skinner, J.A., Mazzini, A., 2009. Martian mud volcanism: Terrestrial analogs and implications for formational scenarios. Mar. Pet. Geol. 26, 1866-1878. doi:10.1016| j.marpetgeo.2009.02.006.

Skinner, J.A., Tanaka, K.L., 2007. Evidence for and implications of sedimentary diapirism and mud volcanism in the southern Utopia highland-lowland boundary plain, Mars. Icarus 186, 41-59. doi:10.1016/j.icarus.2006.08.013.

Soltwedel, T., Portnova, D., Kolar, I., et al., 2005. The small-sized benthic biota of the Håkon Mosby Mud Volcano (SW Barents Sea slope). J. Mar. Syst. 55, 271-290. doi:10.1016/j.jmarsys.2004.09.001.

Somoza, L., 2003. Seabed morphology and hydrocarbon seepage in the Gulf of Cádiz mud volcano area: Acoustic imagery, multibeam and ultra-high resolution seismic data. Mar. Geol. 195, 153-176. doi:10.1016/S0025-3227(02)00686-2.

Sowe, M., Hauber, E., Jaumann, R., et al., 2007. Interior layered deposits in the eastern Valles Marineris and chaotic terrains on Mars. In: Proceedings of the 38th Lunar and Planetary Science Conference. Lunar and Planetary Institute, League City, TX.

Stack, K.M., Grotzinger, J.P., Milliken, R.E., 2013. Bed thickness distributions on Mars: An orbital perspective. J. Geophys. Res.: Planets 118, 1323-1349. doi:10.1002/ jgre.20092.

Stewart, S.A., Davies, R.J., 2006. Structure and emplacement of mud volcano systems in the South Caspian Basin. Am. Assoc. Pet. Geol. Bull. 90, 771-786. doi:10.1306/ 11220505045

Stoppa, F., 2006. The Sirente crater, Italy: Impact versus mud volcano origins. Meteorit. Planet. Sci. 41, 467-477. doi:10.1111/j.1945-5100.2006.tb00474.x.

Tanaka, K.L., 2003a. Resurfacing history of the northern plains of Mars based on geologic mapping of Mars Global Surveyor data. J. Geophys. Res. 108, 8043. doi:10.1029/2002JE001908

Tanaka, K.L., 2003b. Geology of the MER 2003 "Elysium" candidate landing site in southeastern Utopia Planitia, Mars. J. Geophys. Res. 108, 8079. doi:10.1029/ 2003JE002054.

Tanaka, K.L., Fortezzo, C.M., Hayward, R.K., et al., 2011. History of plains resurfacing in the Scandia region of Mars. Planet. Space Sci. 59, 1128-1142. doi:10.1016/j. pss.2010.11.004.

Tanaka, K.L., Robbins, S.J., Fortezzo, C.M., et al., 2014. The digital global geologic map of Mars: Chronostratigraphic ages, topographic and crater morphologic characteristics, and updated resurfacing history. Planet. Space Sci. 95, 11-24. doi:10.1016/j.pss.2013.03.006.

Tanaka, K.L., Skinner, J.A., Hare, T.M., 2005. Geologic Map of the Northern Plains of Mars. U.S. Geological Survey Scientific Investigations Map 2888.

Van Rensbergen, P., 2005. Seafloor expression of sediment extrusion and intrusion at the El Arraiche mud volcano field, Gulf of Cadiz. J. Geophys. Res. 110, F02010. doi:10.1029/2004JF000165.

Van Rensbergen, P., Maltman, A.J., Morley, C.K., 2003. Subsurface Sediment Mobilization, Geological Society, London, Special Publications. Geological Society, London doi:10.1144/GSL.SP.2003.216.01.34.

Vanneste, H., Kastner, M., James, R.H., et al., 2012. Authigenic carbonates from the Darwin Mud Volcano, Gulf of Cadiz: A record of palaeo-seepage of hydrocarbon bearing fluids. Chem. Geol. 300-301, 24-39. doi:10.1016/j.chemgeo.2012.01.006.

Weitz, C.M., NOE Dobrea, E., Wray, J.J., 2015. Mixtures of clays and sulfates within deposits in western Melas Chasma, Mars. Icarus 251, 291-314. doi:10.1016/j. icarus.2014.04.009.

Witbeck, N.E., Tanaka, K.L., Scott, D.H., 1991. Geologic Map of the Valles Marineris Region, Mars. U.S. Geological Survey Map I-2010.

Wrede, C., Brady, S., Rockstroh, S., et al., 2012. Aerobic and anaerobic methane oxidation in terrestrial mud volcanoes in the Northern Apennines. Sediment. Geol. 263-264, 210-219. doi:10.1016/j.sedgeo.2011.06.004.

Yusifov, M., Rabinowitz, P.D., 2004. Classification of mud volcanoes in the South Caspian Basin, offshore Azerbaijan. Mar. Pet. Geol. 21, 965-975. doi:10.1016/j. marpetgeo.2004.06.002. 